\title{
Development of an Assay for Rapid Detection and Quantification of Verticillium dahliae in Soil
}

\author{
Guillaume J. Bilodeau, Steven T. Koike, Pedro Uribe, and Frank N. Martin
}

First, third, and fourth authors: United States Department of Agriculture-Agricultural Research Service, 1636 East Alisal St., Salinas, CA, 93905; and second author: University of California Cooperative Extension Monterey County, 1432 Abbott Street, Salinas 93901. Accepted for publication 25 October 2011.

\section{ABSTRACT}

Bilodeau, G. J., Koike, S. T., Uribe, P., and Martin, F. N. 2012. Development of an assay for rapid detection and quantification of Verticillium dahliae in soil. Phytopathology 102:331-343.

Verticillium dahliae is responsible for Verticillium wilt on a wide range of hosts, including strawberry, on which low soil inoculum densities can cause significant crop loss. Determination of inoculum density is currently done by soil plating but this can take 6 to 8 weeks to complete and delay the grower's ability to make planting decisions. To provide a faster means for estimating pathogen populations in the soil, a multiplexed TaqMan real-time polymerase chain reaction (PCR) assay based on the ribosomal DNA (rDNA) intergenic spacer (IGS) was developed for $V$. dahliae. The assay was specific for $V$. dahliae and included an internal control for evaluation of inhibition due to the presence of PCR inhibitors in DNA extracted from soil samples. An excellent correlation was observed in regression analysis $\left(R^{2}=0.96\right)$ between real-time PCR results and inoculum densities determined by soil plating in a range of field soils with pathogen densities as low as 1 to 2 microsclerotia/g of soil. Variation in copy number of the rDNA was also evaluated among isolates by SYBR Green real-time PCR amplification of the $V$. dahliaespecific amplicon compared with amplification of several single-copy genes and was estimated to range from $\approx 24$ to 73 copies per haploid genome, which translated into possible differences in results among isolates of $\approx 1.8$ cycle thresholds. Analysis of the variation in results of $V$. dahliae quantification among extractions of the same soil sample indicated that assaying four replicate DNA extractions for each field sample would provide accurate results. A TaqMan assay also was developed to help identify colonies of $V$. tricorpus on soil plates.

Additional keywords: rDNA copy number, V. tricorpus.
Strawberry (Fragaria $\times$ ananassa) is an important crop in California, with production representing $\approx 89 \%$ of the fresh and frozen market strawberries produced in the United States for 2009 , with a market value of $\$ 1.7$ billion (7). Estimated yearly production costs are $>\$ 82,000 /$ ha $(\$ 33,000 /$ acre) (33); therefore, disease losses due to soilborne pathogens could have an economic impact for the strawberry producer and are a major reason that nonorganic commercial production fields are fumigated prior to planting. Historically, one of the primary reasons for soil fumigation was for control of the vascular wilt pathogen Verticillium dahliae Kleb. (44). This pathogen has a wide host range and can cause significant losses in highly susceptible crops, such as strawberry, that lack genetic resistance. Soil inoculum densities of as little as 1 to 2 microsclerotia (MS) $\mathrm{g}^{-1}$ of soil can result in plant losses (20) and 7 to $8 \mathrm{MS} \mathrm{g}^{-1}$ of soil can result in $90 \%$ losses in some cases (F. Martin, unpublished). With the phase-out of methyl bromide for soil fumigation $(43,56)$, the longer intervals needed between soil fumigation and planting when using alternative fumigants, and the increase in organic production, there is a need for having a method for rapid and accurate determination of soil inoculum densities of $V$. dahliae.

Corresponding author: F. N. Martin; E-mail address: frank.martin@ars.usda.gov

Mention of trade names or commercial products in this manuscript is solely for the purpose of providing specific information and does not imply recommendation or endorsement by the United States Department of Agriculture.

* The $\boldsymbol{e}$-Xtra logo stands for "electronic extra" and indicates that the online version contains one supplemental figure and one supplemental table.

http://dx.doi.org/10.1094/PHYTO-05-11-0130

This article is in the public domain and not copyrightable. It may be freely reprinted with customary crediting of the source. The American Phytopathological Society, 2012.
Verticillium spp. survive in the soil as MS, which consist of a mass of fungal mycelium surrounded by a rind of tissue high in melanin that protects it from UV light; these structures can survive in the soil for many years in the absence of susceptible hosts $(40,49)$. The current method for determining soil inoculum density involves soil plating onto semiselective media and counting colonies of $V$. dahliae after several weeks of incubation. Both wet and dry sieving techniques have been developed but an interlaboratory ring trial showed inconsistency in results between the techniques $(18,63)$. Furthermore, it is not possible to differentiate colonies of $V$. dahliae from the crucifer pathogen $V$. longisporum (V. dahliae var. longisporum C. Stark [61]; comb. nov. Karapapa, Bainbr. \& Heale [32]) and, in some cases, from colonies produced by Verticillium tricorpus I. Isaac, that are nonpathogenic on strawberry. These other species can be encountered in areas of California where strawberry is grown and, therefore, may potentially influence the accuracy of the plate counts (S. Koike, unpublished). The dry sieving technique is commonly used in California but this technique can take 6 to 8 weeks to get results (29). This timeline can be too long when strawberry growers have planting decisions to make; therefore, techniques that could provide accurate results more quickly would be a benefit to the industry.

One approach to provide a faster means of pathogen detection and quantification in the soil is the use of polymerase chain reaction (PCR) techniques. Conventional PCR assays using single $(30,45)$ or nested amplifications (53) have been described for detection of $V$. dahliae. Techniques for quantifying this pathogen in plant tissue $(11,26,37)$ and soil $(40)$ have also been reported, using competitive PCR with an internal control (IC) for relative quantification of $V$. dahliae. However, techniques using real-time PCR will provide a more accurate quantification of the pathogen with a higher level of sensitivity. Schena et al. $(58,59)$ reported a real-time PCR technique using scorpion primers designed against 
species-specific sequences of the intergenic region (IGS) of the ribosomal DNA (rDNA) repeat as a target to detect $V$. dahliae in olive trees; however, an IC to evaluate whether PCR inhibitors in the extracted DNA were affecting the results was not included. Lievens et al. (38) reported a SYBR Green assay targeting the internal transcribed spacer (ITS) region of the rDNA for quantification of a Verticillium sp. infecting tomato that included an exogenous IC DNA amplified in a separate well to allow for relative quantification. More recently, Atallah et al. (2) developed a quantification assay for $V$. dahliae in potato using Plexor (Promega Corp., Madison, WI) real-time PCR targeting the singlecopy $\beta$-tubulin gene. A plant DNA target was also multiplexed in the amplification and the ratio between the results of the pathogen/potato plant target was used to quantify the pathogen. Given how important it is for the California strawberry industry to have a soil quantification assay for $V$. dahliae sensitive enough to be able to detect pathogen inoculum densities as low as 1 to $2 \mathrm{MS} / \mathrm{g}$ of soil, it was believed that a new technique needed to be developed focusing on a high-copy-number target sequence that would have the added specificity of a TaqMan probe in addition to primer sequence specificity to reduce potential problems with nonspecific amplification. Recently, several potential real-time PCR soil quantification methods were presented at the 10th International Verticillium symposium but were not available for evalutation in California $(12,51,65)$.

There are several challenges for developing a molecular quantification assay for soilborne fungal plant pathogens, including the ability to efficiently disrupt the resting structures present in the soil in order to extract the DNA and provide intact DNA template of sufficient purity that PCR inhibitors do not affect the amplification efficiency of the assay. DNA extraction procedures for soilborne pathogens (including Verticillium spp.) have been evaluated with variable success. Methods using liquid nitrogen and phenol-chloroform DNA extraction combined with adding powdered skim milk to reduce PCR inhibition were used for $\mathrm{Fu}$ sarium oxysporum f. sp ciceris Matuo \& K. Sato (16), V. tricorpus (24), and $V$. dahliae $(50,62)$. Lees et al. (36) also used phenolchloroform in conjunction with glass beads and a bead beater for assaying Rhizoctonia solani Kühn in potato tissue and soil. Commercial kits were used with a FastPrep homogenization instrument (MP Biomedical, Solon, OH) for detection of Rhizoctonia spp. from soil (47). Rather than using mechanical disruption, pressure cycling technology was evaluated for improving DNA extraction from soil for detection of Rhizoctonia and Pythium spp. (46). For some of these methods, reagents such as powdered skim milk, polyvinylpyrrolidone, and polyvinylpolypyrrolidone were added to remove PCR inhibitors during DNA extraction; however, these additions were not always effective in doing this.

The most common approach used to address problems with PCR inhibitors has been to dilute the DNA extract and retry amplification. Although this may eventually allow for amplification, it will reduce the sensitivity of the assay due to dilution of target sequences. Because of this, DNA dilution may not be useful when trying to quantify low levels of pathogen inoculum. This approach can also lead to inaccurate results unless there is some mechanism to detect whether PCR inhibitors are affecting the amplification efficiency of the target DNA; just because there is amplification does not mean that PCR inhibitors are not reducing amplification efficiency and shifting the cycle threshold $\left(\mathrm{C}_{\mathrm{t}}\right)$ higher, leading to incorrect conclusions. One technique used to assess the impact of inhibitors is to include an IC in the amplification mixture, an approach that has been used in detection of hepatitis virus $(39,62)$, Enterovirus spp. (19), or Enterococcus spp. (22) in water samples. Perhaps the optimal method is to add a standardized amount of target DNA to the amplification master mix that is designed to be amplified with the same primers used to amplify pathogen template but has a different TaqMan probe and, thus, can be multiplexed in the same amplification. If there is a change in amplification of this IC multiplexed with the pathogen DNA compared with a control amplification with the IC alone, this is an indication that PCR inhibitors are present and altering the accuracy of the assay. It is essential that an IC be included in soil quantification molecular assays where differences in soil type or cropping histories of the field may result in differing levels of PCR inhibitors making it through the DNA extraction procedures.

Having an accurate real-time PCR procedure for soil quantification of $V$. dahliae will reduce the time needed for soil assays from 6 to 8 weeks to a matter of days, thereby providing growers more lead time to make planting decisions. It would also eliminate questions about the correct identification of $V$. dahliae, $V$. longisporum, and sometimes $V$. tricorpus colonies in soil plating assays, thereby improving the accuracy of results. The objectives and approach of this research were to (i) develop a real-time PCR diagnosis and quantification assay for V. dahliae; (ii) develop an IC to determine whether PCR inhibitors in DNA extracted from soil were influencing the amplification of $V$. dahliae target sequences and, thus, the accuracy of results; and (iii) validate the method by comparing the results of the molecular assay with a soil plating assay using different types of field soil.

\section{MATERIALS AND METHODS}

Verticillium isolates. All isolates of Verticillium spp. used in this study are listed in Table 1 and represent most of the recognized Verticillium spp. (56). Mycelia were grown and the DNA extracted following the procedures described by Qin et al. (56) and Collado-Romero et al. (9). Isolate Ls331a from lettuce (Lactuca sativa L.) was used as the positive control and for the serial dilution for the standard curves. Assays for $V$. tricorpus used isolate Ls443 from lettuce for positive controls and standard curves.

Isolation of soil fungi. To evaluate the potential of common soil fungi to interfere with the Verticillium detection assay, $1 \mathrm{~g}$ of field soil from a commercial California strawberry production field (Elder sandy loam) was diluted in $9 \mathrm{ml}$ of sterile water, and seven 1:10 serial dilutions were done. A total of 100 to $500 \mu \mathrm{l}$ of each dilution was plated on 10 plates of potato dextrose agar (PDA)-rose-Bengal medium (PDA, rose Bengal at $40 \mu \mathrm{g} / \mu \mathrm{l}$, rifampicin at $10 \mu \mathrm{g} / \mathrm{ml}$, and ampicillin at $250 \mu \mathrm{g} / \mathrm{ml}$ ), which is a modification of the medium reported by Dhingra and Sinclair (14). Five plates were incubated at $24^{\circ} \mathrm{C}$ and five at $32^{\circ} \mathrm{C}$ for 2 days. Morphologically different colonies were transferred to new plates and incubated at their respective temperatures. Pure cultures were grown in potato dextrose broth (Difco, BD, Franklin Lakes, $\mathrm{NJ}$ ) at $32^{\circ} \mathrm{C}$ for several days and DNA was extracted using the Fast DNA Spin Kit and the lysis buffer (CLS-Y) for fungi provided by the manufacturer (MP Biomedical). The ITS region was amplified using primers ITS 1 and 4 using the procedures of White et al. (68), and the amplicon was sequenced at the Nucleic Acid Sequencing Facility at the Penn State University (University Park, PA). Taxonomic identification of the isolates was done by BLAST analysis against GenBank (1). DNA from a total of 27 fungal isolates representing a range of Aspergillus, Chaetosartorya, Eupenicillium, Fusarium, Geomyces, Mucor, Penicillium, and Ulocladium spp. (Supplemental Material S1) were included in evaluations of marker specificity.

Verticillium sp.-specific probe and primers design. To help facilitate detection of low inoculum levels of the pathogen, the high-copy-number IGS from rDNA was used to design primers and probe. An alignment of 65 IGS sequences of different Verticillium spp. (V. dahliae, V. albo-atrum, V. tricorpus, and V. longisporum) from Qin et al. (56) (PopSet alignment GI: 76781573) was used to design species-specific PCR primers and probes for $V$. dahliae and V. tricorpus (Table 2). The software IDT SciTools OligoAnalyzer 3.1 (Integrated DNA Technologies Inc., Coralville, IA) was used for primer design. Specific primers were designed 
so that the nucleotides unique to the target were at the $3^{\prime}$ end position of the primer, the amplicons were $<200 \mathrm{bp}$, and a TaqMan probe (23) could be designed in the middle of the amplicon. For the TaqMan probe design, the following parameters were used: annealing temperature $10^{\circ} \mathrm{C}$ higher than the amplification primers, 15 to $30 \mathrm{bp}$ in length, and the total number of Gs or Cs in the last five nucleotides at the $3^{\prime}$ end of the probe not exceeding two. Mismatching nucleotides responsible for species specificity were positioned as close as possible to the middle of the probe rather than at the ends while avoiding positions with secondary structure (15). The 5' end of the TaqMan probe for $V$. dahliae was labeled with FAM (fluorescein) and for V. tricorpus with CAL FluorRed 610 (Table 2). The 3' end of all probes was labeled with the Black Hole Quencher-1 (BHQ1; Biosearch Technologies, Inc., Novato, CA). The amplification master mix contained $1.0 \mu \mathrm{M}$ each of the species-specific primer pair, $0.4 \mu \mathrm{M}$ TaqMan probe, $1.5 \mathrm{mM} \mathrm{MgCl}_{2}$, and Real Master Mix without Rox (5 Prime; Fisher Scientific, Waltham, MA) with PCR cycling conditions set at $95^{\circ} \mathrm{C}$ for $2 \mathrm{~min}$ and 55 cycles at $95^{\circ} \mathrm{C}$ for $15 \mathrm{~s}$ and $62^{\circ} \mathrm{C}$ for $30 \mathrm{~s}$, in a reaction volume of $25 \mu \mathrm{l}$ on the ICycler instrument (IQ4; Bio-Rad Laboratories, Hercules, CA). The amplification conditions were the same for $V$. tricorpus, with the exception that $0.5 \mu \mathrm{M}$ amplification primers (IGS_Vtric_1F and IGS_Vtric_1R) (Table 2), $0.2 \mu \mathrm{M}$ Vtrico_probe, and $6 \mathrm{mM} \mathrm{MgCl}_{2}$ were used with cycling conditions set at $95^{\circ} \mathrm{C}$ for $1.5 \mathrm{~min}$ and 55 cycles at $95^{\circ} \mathrm{C}$ for $15 \mathrm{~s}$ and $57^{\circ} \mathrm{C}$ for $30 \mathrm{~s}$.

Copy number of rDNA in $\boldsymbol{V}$. dahliae. To estimate the number of rDNA repeat units present in the nuclear genome and evaluate whether there was intraspecific variation that could compromise the accuracy of pathogen quantification, three single-copy genes (endochitinase, glyceraldehyde-3-phosphate dehydrogenase [G3PD], and $\beta$-tubulin) were selected based on analysis of the genome sequences of $V$. dahliae and V. albo-atrum (http://www.broadinstitute. org/annotation/genome/Verticillium_dahliae/MultiHome.html) and primers were designed to amplify a fragment of $\approx 160 \mathrm{bp}$ for each of these three genes (Table 3). BLAST analysis with the genome of $V$. dahliae Ls17 was used to confirm that these represented single-copy genes. Amplifications of the $V$. dahliae IGS speciesspecific target sequence and the single-copy genes were done individually using SYBR Green with the master mix containing $0.4 \mu \mathrm{M}$ forward and reverse primer, $1.5 \mathrm{mM} \mathrm{MgCl}_{2}$ and $1 \times \mathrm{SYBR}$ Green Universal PCR Master Mix (Applied Biosystems Inc., Foster City, CA) in a reaction volume of $25 \mu$ with each template run in duplicate. DNA templates from $11 \mathrm{~V}$. dahliae isolates from different hosts and geographic locations (Table 1) were used with an approximate concentration of $1 \mathrm{ng} / \mu \mathrm{l}$ determined on a ND1000 NanoDrop spectrophotometer (NanoDrop Products, Wilmington, DE). PCR cycling conditions were set at 1 cycle at $50^{\circ} \mathrm{C}$ for $2 \mathrm{~min}, 1$ cycle at $95^{\circ} \mathrm{C}$ for $10 \mathrm{~min}, 55$ cycles at $95^{\circ} \mathrm{C}$ for $15 \mathrm{~s}$ and $60^{\circ} \mathrm{C}$ for $30 \mathrm{~s}$, and a melting curve with 60 cycles from $55^{\circ} \mathrm{C}$ increasing at each cycle by $0.5^{\circ} \mathrm{C}$. The difference of the mean $\mathrm{C}_{\mathrm{t}}$ value between the IGS region and each single-copy locus was calculated for individual $V$. dahliae isolates to estimate the copy number using Excel 2003 (Microsoft, Redmond, WA) (Table 4).

Design of the IC. To serve as an internal reference for each amplification to identify whether there was any alteration in amplification efficiency due to the presence of PCR inhibitors, an IC was developed using a cloned mitochondrial plasmid from Pythium aphanidermatum isolate 96-4 (42). The plasmid was initially cloned into the HindIII site of the multiple cloning site in pBluescript (Stratagene, La Jolla, CA) and had been subsequently subcloned into pUC119 (pUC96-4) (Fig. 1). The forward and reverse amplification primers were designed based on plasmid sequences and the multiple cloning sites for pUC119, respectively, with binding sites for the forward and reverse amplification primers for $V$. dahliae tailed on so that the IC would amplify in $V$. dahliae assays without the need for a second set of amplification primers. The TaqMan probe (PPF_Probe_543) was designed following the procedure mentioned in the previous section with the sequence including regions of the Pythium plasmid and portions of the multiple cloning sites of pBluescript and pUC119 (Fig. 1). The targeted amplicon was $121 \mathrm{bp}$ and the amplification conditions to generate this amplicon were $0.4 \mu \mathrm{M}$ each hybrid primer (Vdf929-PPF1F, CGTTTCCCGTTACTCTTCTTAGA ATAATATATATAACGCGT and Vdr1076-PPF1R, GGATTTCG GCCCAGAAACTCCAAGCTTGCATGCCT) (underlined sequences represent the $V$. dahliae primer sequences), $0.2 \mathrm{mM}$ dNTPs, $2 \mathrm{mM} \mathrm{MgCl}$, $1 \times$ reaction buffer, and 1.25 units of AmpliTaq DNA Polymerase (Applied Biosystems Inc.), and template DNA (pUC96-4 purified plasmid). PCR cycling conditions to generate the IC amplicon were $95^{\circ} \mathrm{C}$ for $3 \mathrm{~min}$ and 40 cycles at $95^{\circ} \mathrm{C}$ for $1 \mathrm{~min}, 60^{\circ} \mathrm{C}$ for $45 \mathrm{~s}$, and $72^{\circ} \mathrm{C}$ for $1 \mathrm{~min} 30 \mathrm{~s}$ in a reaction volume of $25 \mu \mathrm{l}$. After evaluation of this amplicon on a $2 \%$ Seakem agarose electrophoresis gel (Cambrex, Charles City, IA) and staining with ethidium bromide to confirm amplification, the PCR amplification mixture was treated with ExoSap-IT (USB Corporation, Cleveland) following the manufacturer's instructions to remove residual primers and dNTPs. To determine the concentration of the IC that should be added to the amplification master mix of the $V$. dahliae assay, a dilution series from $10^{-2}$ to $10^{-12}$ of this amplicon was tested. The TaqMan probe was labeled with $\mathrm{Cy} 5$ at the $5^{\prime}$ end and with the quencher Iowa Black RQ at the $3^{\prime}$ end (Integrated DNA Technologies Inc.). Preliminary evaluations determined that $1 \mu \mathrm{l}$ of the $10^{-9}$ dilution $(0.2 \mathrm{fg} / \mu \mathrm{l})$ of the IC amplicon had a $\mathrm{C}_{\mathrm{t}}$ of $\approx 30$ to 31 while the $10^{-10}$ dilution $(0.02 \mathrm{fg} / \mu \mathrm{l})$ was $\approx 34$ to 36 (data not shown). In multiplexed amplifications with the $V$. dahliae marker, the IC probe (PPF_Probe_543) was added to the amplification master mix at a concentration of $0.2 \mu \mathrm{M}$.

DNA extraction from soil. Soil samples $(500 \mathrm{mg}$ of air-dried soil) were placed in the 2-ml DNA extraction tubes for the FastDNA spin kit for soil (MP Biomedical), frozen in liquid nitrogen for $2 \mathrm{~min}$, and then put in a water bath $\left(70^{\circ} \mathrm{C}\right)$ for $2 \mathrm{~min}$. These two steps were repeated for a total of three cycles before addition of lysing matrix E, $978 \mu \mathrm{l}$ of sodium phosphate buffer, and $122 \mu \mathrm{l}$ of MT buffer. The tubes were placed in a FastPrep homogenization instrument (MP Biomedical) and homogenized at a setting of 6.5 for $45 \mathrm{~s}$. The manufacturer's recommendations were followed for subsequent steps of DNA extraction, with a final elution volume of $50 \mu \mathrm{l}$. The DNA was further purified using components from the Quick Pick kit (BioNobile, Parainen, Finland). DNA extract $(20 \mu \mathrm{l})$ was put in a $1.5-\mathrm{ml}$ tube, and $10 \mu \mathrm{l}$ of plant DNA MagaZorb magnetic particles and $250 \mu \mathrm{l}$ of plant DNA binding buffer was added. This was mixed continuously during incubation at room temperature for $10 \mathrm{~min}$. The tube was placed in the Dynal MPC Magnet rack (Invitrogen, Carlsbad, CA) and, once the paramagnetic beads were attached to the side of the tube, the liquid was removed. A volume of $400 \mu \mathrm{l}$ of plant DNA wash buffer was added and the tubes were mixed with quick finger flicks prior to replacing in the magnet rack for $1 \mathrm{~min}$ before removing the liquid. This washing was repeated. The DNA was eluted with $20 \mu \mathrm{l}$ of plant DNA elution buffer by gentle mixing at room temperature for $10 \mathrm{~min}$. The magnetic particles were collected on the side of the tube with the magnetic rack and the eluted DNA transferred into a new tube.

Quantification of $\boldsymbol{V}$. dahliae in field soil. Soil samples were collected from commercial strawberry and lettuce fields in different production areas in California (Table 5). Inoculum densities of $V$. dahliae in these soils were assayed using NP-10 semiselective medium and standard plate count methods following the procedure of Kabir et al. (29), with some modifications. Soils were air-dried at room temperature $\left(23 \pm 2{ }^{\circ} \mathrm{C}\right)$, mixed thoroughly, and pulverized with a mortar and pestle. The samples were then passed through a 20-mesh sieve to remove hard particles and stones. For each sample, $10 \mathrm{~g}$ of the sieved soil was placed in 
vials along with $3 \mathrm{ml}$ of a methionine solution $(7.5 \mathrm{mg} / \mathrm{ml})(31)$. Vials were sealed and incubated in the dark for 1 week at $30^{\circ} \mathrm{C}$. After this incubation, vials were opened and allowed to air dry at room temperature for an additional week. The dry samples were repulverized and stored until tested for Verticillium spp. Prepared soils were evenly distributed onto the agar surfaces of $100-\mathrm{mm}$ petri plates containing NP-10 semiselective medium for $V$. dahliae $(29,60)$ using the modified Anderson air sampler $(6,35)$. For each sample, $0.5 \mathrm{~g}$ of soil was distributed onto six petri plates. For six soils that had very low inoculum densities (soils 05, 07, 25, 29, 30, and 31) (Table 5), $1.0 \mathrm{~g}$ of soil was distributed on a total of 12 plates to improve the accuracy of the results obtained. Plates were subsequently stored in plastic sleeves and incubated in the dark at $23 \pm 2{ }^{\circ} \mathrm{C}$ for 3 weeks. After incubation, agar surfaces were gently rubbed by hand under running water to remove soil particles. Washed plates were drained and then examined for the presence of microsclerotial colonies of $V$. dahliae by viewing plates with a dissecting microscope having a transmitted light source. Some colonies were observed that were difficult to classify as $V$. dahliae or $V$. tricorpus. In these instances, a transfer needle was used to remove part of the colony from the agar surface (taking care to limit the amount of agar transferred) and DNA was extracted using the same procedures as for DNA extraction from soil, with the exception that one colony was used instead of $500 \mathrm{mg}$ of soil. Samples were assayed individually with the $V$. dahliae and $V$. tricorpus TaqMan assay to conclusively determine the correct classification of the colony.

For soil quantification of the pathogen using the $V$. dahliae quantification molecular assay, DNA was extracted from $500 \mathrm{mg}$ of air-dried field soil using the method described above. The DNA samples were assayed in multiplexed amplifications for $V$. dahliae with the IC added at $10^{-10}$ as described above; all samples were run in duplicate on the same 96-well plate. To determine the relationship between soil plate counts of inoculum density and results from the TaqMan real-time PCR quantification assay, regression analysis was conducted using Microsoft Excel 2003.

Evaluation of DNA extraction procedure with different soil types. Soils were collected from commercial strawberry fields in different production districts in California to evaluate the effectiveness of the DNA extraction procedure for removing contaminants that will reduce the efficiency of PCR amplification, thereby providing DNA of sufficient quality for conducting quantification

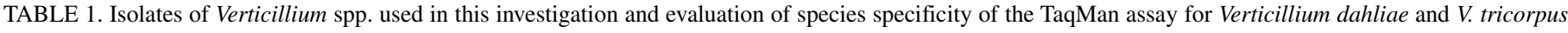
evaluated with fungal DNA present at $1 \mathrm{ng} / \mu 1^{\mathrm{a}}$

\begin{tabular}{|c|c|c|c|c|c|c|}
\hline Isolate & Species & Host & Origin & $\mathrm{VCG}^{\mathrm{b}}$ & V. dahliae $\mathrm{C}_{\mathrm{t}}$ & V. tricorpus $\mathrm{C}_{\mathrm{t}}$ \\
\hline $\mathrm{V} 48 \mathrm{I}^{\mathrm{c}}$ & V. albo-atrum & Hop & United Kingdom & - & N/A & N/A \\
\hline $\mathrm{Ms} 102^{\mathrm{d}}$ & V. albo-atrum & Alfalfa & Pennsylvania, United States & - & N/A & N/A \\
\hline CHILE1 ${ }^{\mathrm{e}}$ & V. albo-atrum & Kiwi & Chile & - & N/A & N/A \\
\hline PSU140e & V. albo-atrum & Alianthus & Pennsylvania, United States & - & $\mathrm{N} / \mathrm{A}^{\mathrm{f}}$ & N/A \\
\hline VAA $383^{\mathrm{e}}$ & V. albo-atrum & Potato & Ontario, Canada & - & $\mathrm{N} / \mathrm{A}^{\mathrm{f}}$ & N/A \\
\hline $462^{\mathrm{e}}$ & V. albo-atrum & Potato & Minnesota, United States & - & N/A & N/A \\
\hline $48557^{\mathrm{e}}$ & V. albo-atrum & Tomato & England & - & $\mathrm{N} / \mathrm{A}^{\mathrm{f}}$ & N/A \\
\hline Vaa4ATC & V. albo-atrum & Potato & Ontario, Canada & - & $N / A^{f}$ & N/A \\
\hline $1852^{\mathrm{g}, \mathrm{h}}$ & V. albo-atrum & Potato soil & Cuba & - & $N / A^{f}$ & N/A \\
\hline $1856^{\mathrm{g}, \mathrm{h}}$ & V. albo-atrum & Potato & Manitoba, Canada & - & N/A & N/A \\
\hline $5009^{\mathrm{g}, \mathrm{h}}$ & V. albo-atrum & Potato & P.E.I., Canada & - & N/A & N/A \\
\hline $4901^{\mathrm{g}, \mathrm{i}}$ & V. albo-atrum & Potato soil & P.E.I., Canada & - & $\mathrm{N} / \mathrm{A}^{\mathrm{f}}$ & N/A \\
\hline V104g,i & V. albo-atrum & Potato soil & P.E.I., Canada & - & $\mathrm{N} / \mathrm{A}^{\mathrm{f}}$ & N/A \\
\hline $\mathrm{V} 112^{\mathrm{g}, \mathrm{i}}$ & V. albo-atrum & Potato soil & P.E.I., Canada & - & N/A & N/A \\
\hline CBS451.88 & V. albo-atrum & Unknown & Belgium & - & N/A & N/A \\
\hline CBS321.91 ${ }^{\mathrm{j}}$ & V. albo-atrum & Tomato & The Netherlands & - & N/A & N/A \\
\hline CBS385.91 & V. albo-atrum & Tomato & The Netherlands & - & N/A & N/A \\
\hline $\mathrm{Ca}_{6} 3^{\mathrm{d}}$ & V. dahliae & Bell pepper & California, United States & - & 22.1 & N/A \\
\hline $\mathrm{Cf} 40^{\mathrm{d}}$ & V. dahliae & Chili pepper & California, United States & - & 23.9 & N/A \\
\hline $\mathrm{Cf} 45^{\mathrm{d}, \mathrm{k}}$ & V. dahliae & Chili pepper & California, United States & - & 19.9 & N/A \\
\hline $\mathrm{Cs} 80^{\mathrm{d}, \mathrm{k}}$ & V. dahliae & Artichoke & California, United States & 2 & 19.6 & N/A \\
\hline Cv79d & V. dahliae & Watermelon & California, United States & - & 20.9 & N/A \\
\hline $\mathrm{Cv} 85^{\mathrm{d}}$ & V. dahliae & Watermelon & California, United States & 2 & 22.3 & N/A \\
\hline Fca $21^{\mathrm{d}, \mathrm{k}}$ & V. dahliae & Strawberry & California, United States & 2 & 20.8 & N/A \\
\hline Fca29d,k & V. dahliae & Strawberry & California, United States & - & 19.9 & N/A \\
\hline Gh101 ${ }^{\mathrm{d}}$ & V. dahliae & Cotton & California, United States & 1 & 22.2 & N/A \\
\hline Le88 ${ }^{\mathrm{d}, \mathrm{k}}$ & V. dahliae & Tomato & California, United States & 4 & 21.7 & N/A \\
\hline $\operatorname{Ls} 17^{\mathrm{d}, \mathrm{k}}$ & V. dahliae & Lettuce & California, United States & - & 19.8 & N/A \\
\hline $\mathrm{Ls} 7^{\mathrm{d}}$ & V. dahliae & Lettuce & California, United States & 2 & 21.2 & N/A \\
\hline${\mathrm{Mp} 89^{\mathrm{d}}}$ & V. dahliae & Mint & Oregon, United States & 2 & 20.3 & N/A \\
\hline
\end{tabular}

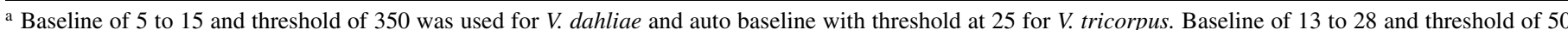
was used for the internal control (IC). The IC was also run with the $V$. dahliae assay to evaluate competition. IC amplicon of $10^{-10}$ dilution was used to test polymerase chain reaction inhibition. No inhibition was observed with a cycle threshold $\left(\mathrm{C}_{t}\right)$ of 33 to 35 . N/A = no amplification and nt $=$ not tested.

b VCG = vegetative compatibility group, HSI = heterokaryon self-incompatible and $-=$ means not determined.

c DNA provided by Rafael M. Jiménez-Díaz, Universidad de Córdoba, Spain; Collado-Romero et al. $(8,9)$.

${ }^{\mathrm{d}}$ Isolates used by Qin et al. (56).

e DNA provided by Katherine Dobinson, Agriculture and Agrifood Canada, London, ON, Canada.

${ }^{f} \mathrm{C}_{\mathrm{t}}$ value $>40$ cut-off, background amplification.

g DNA provided by Bud Platt, Agriculture and Agrifood Canada, Charlottetown, Prince Edward Island (P.E.I.), Canada.

${ }^{\text {h }}$ Determined as a $V$. albo-atrum group 1.

i Determined as a V. albo-atrum group 2.

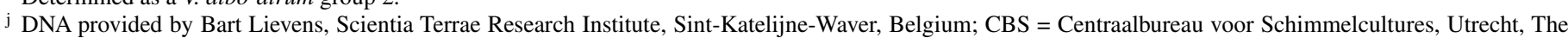
Netherlands; MUCL = Mycothèque de l'Université Catholique de Louvain, Louvain-la-Neuve, Belgium.

${ }^{\mathrm{k}}$ Isolates used for evaluating intraspecific intergenic spacer copy number variation.

${ }^{1} V$. dahliae Ls331a DNA used for standard curve.

${ }^{\mathrm{m}}$ Cultures provided by Lindsey du Toit, Washington State University Mount Vernon Northwestern Washington Research and Extension Center.

${ }^{n}$ No DNA template control. 
assays for $V$. dahliae. The percent sand, silt, and clay, as well as soil $\mathrm{pH}$, were determined at the University of California-Davis Analytical Laboratory using standard techniques (http://anlab. ucdavis.edu). Because $V$. dahliae was not present in all of these samples, the amplification of the IC was used to assess the presence of PCR inhibitors. The real-time PCR amplification mixture was spiked with the IC at a concentration of $10^{-10}$ and the IC amplification was compared with control wells containing the IC in water.

\section{RESULTS}

Verticillium markers and IC development. Based on the alignment of 65 IGS sequences from different Verticillium spp., PCR primers and a TaqMan probe were designed for detection of $V$. dahliae and $V$. tricorpus (Table 2). All 40 isolates of $V$. dahliae were amplified with the $V$. dahliae species-specific primers and probe whereas no amplification occurred with any of the other Verticillium spp. (Table 1). Background amplification was not observed for the 28 isolates representing a range of soil fungi commonly encountered in strawberry production fields (data not shown). Likewise, the primer pair and probe for V. tricorpus was species specific and amplified all isolates of this species evalu- ated. There was a linear relationship between log of DNA concentration and $\mathrm{C}_{\mathrm{t}}$ for both the $V$. dahliae and $V$. tricorpus speciesspecific markers (Fig. 2A and B).

The IC designed from the cloned mitochondrial plasmid of $P$. aphanidermatum isolate 96-4 amplified with the $V$. dahliaspecific primer pair and gave a positive result in TaqMan realtime PCR with the IC probe but was negative when tested with the $V$. dahlia-specific TaqMan probe (data not shown). Conversely, the IC probe did not anneal to amplified $V$. dahliae target DNA. Under the amplification conditions used in these experiments, a dilution of the amplified IC to $10^{-9}$ (amplification product at $0.2 \mathrm{fg} / \mu \mathrm{l}$ ) had a $\mathrm{C}_{\mathrm{t}}$ of $\approx 31$ while a $10^{-10}$ dilution (amplification product at $0.02 \mathrm{fg} / \mu \mathrm{l}$ ) had a $\mathrm{C}_{\mathrm{t}}$ of $\approx 34$ in singleplex amplifications.

Estimation of rDNA copy number in $\boldsymbol{V}$. dahliae. The copy number of the rDNA region of $V$. dahliae was estimated by realtime PCR amplification by comparing the mean $\mathrm{C}_{\mathrm{t}}$ of the singlecopy genes endochitinase, G3PD, and $\beta$-tubulin with the result obtained for the $V$. dahliae species-specific amplification based on the IGS region of the rDNA. At a total DNA concentration of $\approx 1$ ng/amplification, the single-copy genes had a $C_{t}$ value of 21 to 24 , depending on the isolate used, with variation in the $\mathrm{C}_{\mathrm{t}}$ between replicates generally $<0.8$ (not shown). In general, mean $\mathrm{C}_{t}$ differences between the IGS region and individual single-copy

TABLE 1. (continued from preceding page)

\begin{tabular}{|c|c|c|c|c|c|c|}
\hline Isolate & Species & Host & Origin & $\mathrm{VCG}^{\mathrm{b}}$ & V. dahliae $\mathrm{C}_{\mathrm{t}}$ & V. tricorpus $\mathrm{C}_{\mathrm{t}}$ \\
\hline $\mathrm{Sm} 113^{\mathrm{d}}$ & V. dahliae & Eggplant & Maryland, United States & 4 & 22.3 & N/A \\
\hline $\mathrm{St} 91^{\mathrm{d}, \mathrm{k}}$ & V. dahliae & Potato & Oregon, United States & 4 & 21.9 & N/A \\
\hline $\mathrm{V} 137 \mathrm{I}^{\mathrm{c}}$ & V. dahliae & Olive & Spain & $1 \mathrm{~A}$ & 19.4 & N/A \\
\hline $\mathrm{V} 292 \mathrm{I}^{\mathrm{c}}$ & V. dahliae & Cotton & Israel & 4B & 19.5 & N/A \\
\hline $\mathrm{V} 310 \mathrm{I}^{\mathrm{d}, \mathrm{k}}$ & V. dahliae & Israel & Cotton & $4 \mathrm{~B}$ & 19.5 & N/A \\
\hline $\mathrm{V} 314 \mathrm{I}^{\mathrm{c}}$ & V. dahliae & Olive & Spain & $1 \mathrm{~A}$ & 18.7 & N/A \\
\hline $\mathrm{V} 364 \mathrm{I}^{\mathrm{c}}$ & V. dahliae & Olive & Syria & $2 \mathrm{~A}$ & 16.8 & $N / A^{f}$ \\
\hline V396I ${ }^{c}$ & V. dahliae & Artichoke & Spain & $2 \mathrm{~B}$ & 18.7 & $N / A^{f}$ \\
\hline $\mathrm{V} 403 \mathrm{I}^{\mathrm{c}}$ & V. dahliae & Artichoke & Spain & $1 \mathrm{~A}$ & 16.4 & $N / A^{f}$ \\
\hline $\mathrm{V} 532 \mathrm{I}^{\mathrm{c}}$ & V. dahliae & Artichoke & Spain & $2 \mathrm{~B}$ & 18.9 & N/A \\
\hline $\mathrm{V} 537 \mathrm{I}^{\mathrm{c}}$ & V. dahliae & Artichoke & Spain & HSI & 17.7 & N/A \\
\hline V539I ${ }^{c}$ & V. dahliae & Artichoke & Spain & $2 \mathrm{~B}$ & 20.1 & N/A \\
\hline V548I ${ }^{c}$ & $V$. dahliae & Artichoke & Spain & $2 \mathrm{~A}$ & 18.7 & N/A \\
\hline V661I ${ }^{c}$ & V. dahliae & Cotton & Greece & 1B & 16.1 & $N / A^{f}$ \\
\hline $\mathrm{V} 707 \mathrm{I}^{\mathrm{c}}$ & V. dahliae & Artichoke & Spain & $2 \mathrm{~A}$ & 19.4 & $N / A^{f}$ \\
\hline $\mathrm{V} 714 \mathrm{I}^{\mathrm{c}}$ & V. dahliae & Olive & Italy & $2 \mathrm{~A}$ & 19.1 & $N / A^{f}$ \\
\hline $\mathrm{V} 717 \mathrm{I}^{\mathrm{c}}$ & V. dahliae & Olive & Italy & $2 \mathrm{~A}$ & 20 & N/A \\
\hline $\mathrm{V} 792 \mathrm{I}^{\mathrm{c}, \mathrm{k}}$ & V. dahliae & Olive & Spain & $4 B$ & 19.7 & N/A \\
\hline $\mathrm{V}^{2} 800 \mathrm{I}^{\mathrm{c}}$ & V. dahliae & Olive & Spain & $2 \mathrm{~A}$ & 24.7 & N/A \\
\hline $\mathrm{V} 854 \mathrm{I}^{\mathrm{c}, \mathrm{k}}$ & V. dahliae & Cotton & Spain & $1 \mathrm{~A}$ & 18.6 & N/A \\
\hline $\mathrm{V} 870 \mathrm{I}^{\mathrm{c}}$ & V. dahliae & Cotton & Spain & $1 \mathrm{~A}$ & 19 & N/A \\
\hline $69212 A^{g}$ & V. dahliae & Potato & P.E.I., Canada & - & 22.7 & $N / A^{f}$ \\
\hline $\mathrm{C} 026-3^{\mathrm{g}}$ & V. dahliae & Potato & P.E.I., Canada & - & 26.6 & N/A \\
\hline $10010^{\mathrm{g}}$ & V. dahliae & Potato & P.E.I., Canada & - & 24.9 & N/A \\
\hline CBS179.66j & V. dahliae & Tomato & The Netherlands & - & 22.3 & N/A \\
\hline CBS381.66j & V. dahliae & Tomato & Canada & - & 22 & N/A \\
\hline Ls331 $\mathrm{a}^{\mathrm{k}, \mathrm{l}}$ & $V$. dahliae $0.3 \mathrm{ng} / \mu \mathrm{l}$ & Lettuce & California, United States & - & 20.4 & N/A \\
\hline Ls331 $a^{1}$ & $V$. dahliae $0.03 \mathrm{ng} / \mu \mathrm{l}$ & Lettuce & California, United States & $\ldots$ & 25 & nt \\
\hline Ls331 $\mathrm{a}^{1}$ & $V$. dahliae $0.003 \mathrm{ng} / \mu \mathrm{l}$ & Lettuce & California, United States & $\ldots$ & 31.3 & nt \\
\hline Ls331 $\mathrm{a}^{1}$ & $V$. dahliae $0.0003 \mathrm{ng} / \mu \mathrm{l}$ & Lettuce & California, United States & $\ldots$ & N/A & nt \\
\hline Ls331a ${ }^{1}$ & $V$. dahliae $0.00003 \mathrm{ng} / \mu \mathrm{l}$ & Lettuce & California, United States & $\ldots$ & N/A & $\mathrm{nt}$ \\
\hline Bob70 ${ }^{d}$ & V. longisporum & Cauliflower & California, United States & - & N/A & N/A \\
\hline Bob71 ${ }^{\mathrm{d}}$ & $V$. longisporum & Cauliflower & California, United States & - & N/A & N/A \\
\hline $\operatorname{Ar} 136^{\mathrm{d}}$ & V. longisporum & Horseradish & Illinois, United States & - & N/A & N/A \\
\hline V51 $\mathrm{I}^{\mathrm{c}}$ & $V$. nigrescens & Potato & United Kingdom & - & N/A & N/A \\
\hline $\mathrm{VN}-10^{\mathrm{m}}$ & $V$. nigrescens & Spinach & Washington, United States & - & $N / A^{f}$ & N/A \\
\hline MUCL8266j & V. nubilum & Soil & Germany & - & $N / A^{f}$ & N/A \\
\hline $\mathrm{V} 53 \mathrm{I}^{\mathrm{c}}$ & V.tricorpus & Soil & United States & - & N/A & nt \\
\hline $\operatorname{Ls} 442^{\mathrm{d}}$ & $V$. tricorpus & Lettuce & California, United States & - & $N / A^{f}$ & nt \\
\hline $\operatorname{Ls} 443^{d}$ & V. tricorpus & Lettuce & California, United States & - & nt & 16.8 \\
\hline $\mathrm{Cs} 234^{\mathrm{d}}$ & V. tricorpus & Artichoke & California, United States & - & N/A & 19.6 \\
\hline $2931^{\mathrm{g}}$ & V. tricorpus & Soil & Quebec, Canada & - & N/A & 19 \\
\hline $2933^{\mathrm{g}}$ & V. tricorpus & Soil & Quebec, Canada & - & N/A & 22.7 \\
\hline $1901^{\mathrm{g}}$ & $V$. tricorpus & Potato leave & P.E.I., Canada & - & N/A & 33 \\
\hline $\mathrm{VT}-10^{\mathrm{m}}$ & V. tricorpus & Spinach & Washington, United States & - & N/A & 21.8 \\
\hline Control, rep $1^{\mathrm{n}}$ & N/A & $\ldots$ & $\ldots$ & $\ldots$ & N/A & $\ldots$ \\
\hline Control, rep $2^{\text {n }}$ & N/A & $\ldots$ & $\ldots$ & $\ldots$ & N/A & $\ldots$ \\
\hline
\end{tabular}


genes were 5.8 to 6.3 (Table 4), with a mean of 5.9 and standard deviation of 0.4 . Variation of $<13 \%$ was observed for the $C_{t}$ differences between genes. Based on an amplification efficiency of $90.6 \%$ for the IGS assay with a standard dilution of Ls331a DNA, the mean IGS copy number could be estimated using the equation copy number $=1.906^{\mathrm{Ct}}$ difference $(52)$. With a mean $\mathrm{C}_{\mathrm{t}}$ difference of 5.9 , this would represent $\approx 45$ copies of the rDNA per haploid nucleus for $V$. dahliae. The amplification efficiency of the single-copy genes was 97.7, 81.9, 92.1, and $81.5 \%$ for the endochitinase, G3PD, and two $\beta$-tubulin regions, respectively. Because these values were different from the $90.6 \%$ amplification efficiency of the IGS marker, these copy number estimates should be considered approximations. To determine whether there were rDNA copy number differences among isolates of $V$. dahliae, the amplifications were repeated with 11 different isolates with estimated relative copy number differences of $\approx 24$ to 73 per haploid genome.

TABLE 2. Primers and probe used for TaqMan real-time polymerase chain reaction diagnostic assay for detection and quantification of Verticillium dahliae and $V$. tricorpus

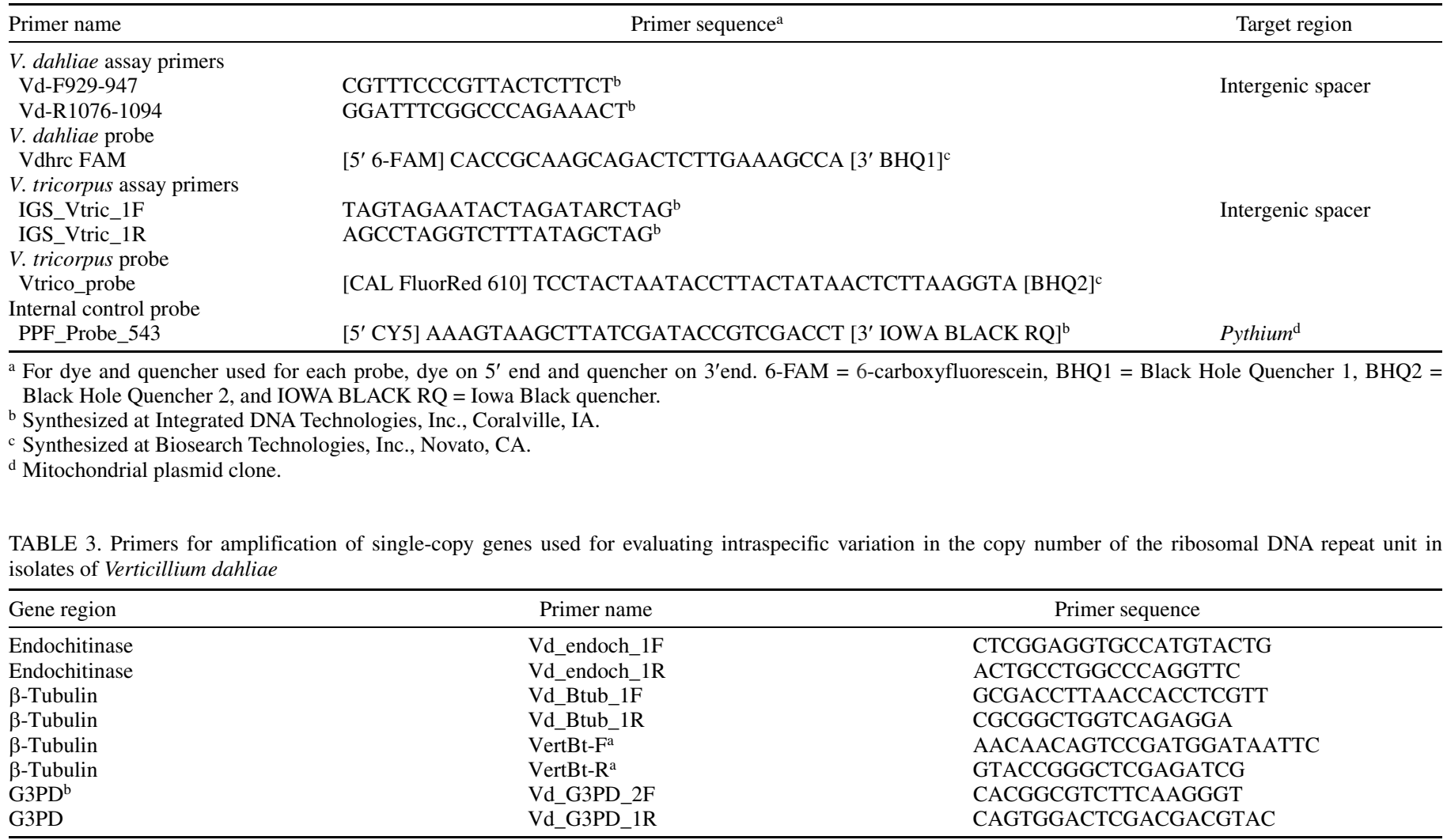

${ }^{a} \beta$-Tubulin primers from Atallah et al. (3).

b G3PD = glyceraldehyde-3-phosphate dehydrogenase.

TABLE 4. Evaluation of ribosomal DNA (rDNA) copy number differences in isolates of Verticillium dahliae by comparing real-time polymerase chain reaction (PCR) results for the rDNA with results for single-copy genes

\begin{tabular}{|c|c|c|c|c|c|c|c|c|}
\hline \multirow[b]{2}{*}{ Isolate } & \multicolumn{4}{|c|}{ Mean $C_{t}$ difference between IGS and single-copy gene region ${ }^{\mathrm{a}}$} & \multirow[b]{2}{*}{ Mean $C_{t}$ diff. ${ }^{b}$} & \multirow[b]{2}{*}{ SD } & \multirow[b]{2}{*}{ Variation $(\%)^{\mathrm{c}}$} & \multirow[b]{2}{*}{ Copy number ${ }^{\mathrm{d}}$} \\
\hline & Endo-IGS & G3PD-IGS & Btub1-IGS & Btub2-IGS & & & & \\
\hline LS331a & 6.3 & 5.1 & 5.5 & 5.4 & 5.6 & 0.5 & 9.2 & 36.4 \\
\hline Cs80 & 6.1 & 5.4 & 6.0 & 5.5 & 5.8 & 0.4 & 6.1 & 40.8 \\
\hline Fca29 & 7.1 & 6.6 & 5.9 & 6.3 & 6.4 & 0.5 & 7.9 & 63.1 \\
\hline Fca21 & 7.4 & 7.0 & 5.8 & 6.4 & 6.7 & 0.7 & 10.5 & 72.9 \\
\hline CF45 & 6.9 & 6.8 & 6.4 & 6.4 & 6.6 & 0.3 & 4.0 & 71.7 \\
\hline V792 I & 5.4 & 5.4 & 5.8 & 5.2 & 5.5 & 0.3 & 4.6 & 33.6 \\
\hline V854 I & 5.6 & 5.4 & 5.8 & 5.9 & 5.7 & 0.2 & 3.9 & 38.9 \\
\hline \multicolumn{9}{|l|}{ Between isolates } \\
\hline Mean $C_{t}$ difference & 6.3 & 5.8 & 5.7 & 5.9 & 5.9 & 0.4 & 7.4 & 45.9 \\
\hline SD & 0.7 & 0.8 & 0.6 & 0.5 & 0.5 & $\ldots$ & $\ldots$ & $\ldots$ \\
\hline Variation (\%) & 10.9 & 13.1 & 11.1 & 8.0 & 9.2 & $\ldots$ & $\ldots$ & $\ldots$ \\
\hline
\end{tabular}

${ }^{a}$ Standard deviations (SDs) of cycle thresholds $\left(\mathrm{C}_{\mathrm{t}} \mathrm{s}\right)$ between PCRs are 0.1-1.0. PCR efficiency of $90.6 \%$ for the intergenic spacer (IGS) region based on standard dilution curve of isolate Ls331a: $1.906^{\mathrm{Ct} \text { difference }}=$ copy number (52). PCR efficiency for the four regions tested was $97.7,81.9,92.1$, and $81.5 \%$, respectively. Gene designations: Endo $=$ endochitinase, $\mathrm{G} 3 \mathrm{PD}=$ glyceraldehyde-3-phosphate dehydrogenase, Btub1 = $\beta$-tubulin (primers Vd_Btub_1F and Vd_Btub_1R), and Btub2 $=\beta$-tubulin (primers VertBt-F and VertBt-R).

${ }^{b}$ Mean $C_{t}$ difference for each single gene.

${ }^{c}$ Percent $C_{t}$ difference variation between regions.

${ }^{d}$ Copy number estimate based on mean $C_{t}$ difference. 
Validation of the molecular detection and quantification assay using field soil. Soil plate counts of $V$. dahliae were 0 to $622 \mathrm{MS} / \mathrm{g}$ of soil, with counts $>100 \mathrm{MS} / \mathrm{g}$ of soil obtained from lettuce fields naturally infested with $V$. dahliae. In some soils, colonies on culture medium were observed that were difficult to identify as $V$. dahliae or $V$. tricorpus; the patterns of microsclerotial production in the colony were similar to $V$. tricorpus and less dense than those normally observed for $V$. dahliae, yet the typical yellow pigment associated with colonies of $V$. tricorpus (17) was not always observed. These colonies were removed from the agar plate and their identification confirmed in individual assays using the $V$. dahliae and $V$. tricorpus TaqMan real-time PCR assay before they were counted. There was an excellent correlation $\left(R^{2}=0.96\right)$ between $C_{t}$ value of the PCR assay and the number of MS per gram of soil based on the plate counts (Table 5; Fig. 3). The correlation was a little lower $\left(R^{2}=\right.$ 0.85 ) when looking only at the data for soils with a plate count of $\leq 14 \mathrm{MS} / \mathrm{g}$ (Supplementary Figure S1B). A count of $\leq 4 \mathrm{MS} / \mathrm{g}$ of soil was found to have a $C_{t}$ of $\approx 32$ in these soils.

The effect of the IC concentration on the results of field soil assays. The concentration of the added IC can have an influence on the accuracy of the amplification results obtained (Fig. 2A; Table 6). As the concentration of $V$. dahliae target DNA increases, there can be competition for primers between the pathogen template and IC, resulting in an increase in the $\mathrm{C}_{t}$ for the IC. Likewise, increasing the concentration of the IC can cause competition for amplification primers, resulting in an increase in the $\mathrm{C}_{\mathrm{t}}$ of $V$. dahliae when the pathogen DNA is present in low amounts (Fig. 2A). For example, in a soil with a low pathogen inoculum density (soil 06 or $11 ; 2 \mathrm{MS} / \mathrm{g}$ of soil) there was an increase in the $\mathrm{C}_{\mathrm{t}}$ for the soil assay for $V$. dahliae when the IC was added (soil 06, $\mathrm{C}_{\mathrm{t}}=35.6$ when the IC was not added versus 36.9 and 37.3 for the $10^{-10}$ and $10^{-9}$ dilution, respectively). Similar results were observed for soil 01 (6 MS/g of soil), although addition of a $10^{-10}$ dilution of the IC did not alter amplification of the $V$. dahliae marker (Table 6). Conversely, high concentrations of $V$. dahliae template can also influence the amplification of the IC as exemplified by soil 24, where the inoculum density of $V$. dahliae was $156 \mathrm{MS} / \mathrm{g}$ of soil. The presence of the IC in this sample had a limited effect on pathogen amplification (at $10^{-9}$ dilution of the IC, there was a slight increase in $\mathrm{C}_{\mathrm{t}}$ for pathogen detection), yet there was an increase in the $\mathrm{C}_{\mathrm{t}}$ for the IC from 30.8 for the water control to 33.2 with the $10^{-9}$ IC dilution (but no amplification for the $10^{-10}$ IC dilution). There also was a lack of amplification of the IC when present at $10^{-10}$ dilution in other field soils that had a high inoculum density (soils 26 and 28) (Table 5). Similar increases in the $\mathrm{C}_{\mathrm{t}}$ for the IC at these dilution levels was also observed in amplifications with increasing concentrations of culture-purified $V$. dahliae DNA added (data not shown).

TABLE 5. Assay of field soils for Verticillium dahliae by standard direct plating methods for determining inoculum densities and by TaqMan real-time polymerase chain reaction (PCR) ${ }^{\mathrm{a}}$

\begin{tabular}{|c|c|c|c|c|}
\hline $\begin{array}{l}\begin{array}{l}\text { Soil samples } \\
\text { (undiluted) }\end{array} \\
\end{array}$ & $\begin{array}{l}\text { V. dahliae } \\
\text { mean } \mathrm{C}_{\mathrm{t}}^{\mathrm{b}}\end{array}$ & SD & $\begin{array}{c}\mathrm{IC} \mathrm{C}_{\mathrm{t}} \text { mean } \\
\left(10^{-10} \text { dilution }\right) \\
\end{array}$ & $\begin{array}{l}\text { V. dahliae } \\
(\mathrm{MS} / \mathrm{g})^{\mathrm{c}}\end{array}$ \\
\hline Soil 01 & 33.4 & 0.4 & 35.8 & 6 \\
\hline Soil 02 & 33.9 & 0.1 & 35.7 & 6 \\
\hline Soil 03 & 34.5 & 0.5 & 35.0 & 4 \\
\hline Soil 04 & 32.4 & 0.1 & 35.4 & 8 \\
\hline Soil $05^{\mathrm{d}}$ & $\mathrm{N} / \mathrm{A}^{\mathrm{e}}$ & $\ldots$ & 34.5 & 2 \\
\hline Soil 06 & 36.9 & 3.3 & 36.3 & 2 \\
\hline Soil 07d & 32.3 & 0.2 & 36.5 & 11 \\
\hline Soil 08 & 33.4 & 1.1 & 36.7 & 6 \\
\hline Soil 09 & 33.4 & 0.4 & $35.8^{f}$ & 4 \\
\hline Soil 10 & 34.8 & 0.4 & 35.3 & 2 \\
\hline Soil 11 & 35.0 & 0.7 & 34.8 & 2 \\
\hline Soil 12 & 35.4 & 0.4 & 34.3 & 2 \\
\hline Soil 13 & 30.5 & 0.1 & 37.5 & 40 \\
\hline Soil 19 & 30.5 & 1.5 & 36.9 & 12 \\
\hline Soil 20 & 33.7 & 1.1 & 37.2 & 6 \\
\hline Soil 22 & $\mathrm{~N} / \mathrm{A}^{\mathrm{e}}$ & $\ldots$ & 34.1 & 0 \\
\hline Soil 23 & N/A & $\ldots$ & 34.9 & 0 \\
\hline Soil 24 & 26.1 & 0.2 & N/A & 156 \\
\hline Soil $25^{\mathrm{f}}$ & 36.4 & 1.1 & 36.2 & 1 \\
\hline Soil 26 & 22.4 & 0.1 & N/A & 622 \\
\hline Soil 27 & 31.0 & 0.1 & 36.7 & 14 \\
\hline Soil 28 & 25.2 & 0.3 & N/A & 126 \\
\hline Soil $29^{\mathrm{d}}$ & 31.5 & 0.8 & $39.4^{\mathrm{f}}$ & 12 \\
\hline Soil $30^{\mathrm{d}}$ & 32.9 & 0.7 & $37.1^{\mathrm{f}}$ & 4 \\
\hline Soil $31^{\mathrm{d}}$ & N/A & $\ldots$ & 34.4 & 0 \\
\hline $\mathrm{H}_{2} \mathrm{O}$ & N/A & $\ldots$ & 34.2 & $\ldots$ \\
\hline
\end{tabular}

a $\mathrm{SD}=$ standard deviation, $\mathrm{IC}=$ internal control, and N/A = no amplification.

${ }^{b}$ Mean cycle threshold $\left(\mathrm{C}_{\mathrm{t}}\right)$ of two PCR replicates.

c Plate count, microsclerotia per gram of soil.

${ }^{\mathrm{d}}$ For those soils, 12 plates were used for the plate count instead of 6 to provide greater accuracy with the low inoculum density.

e Only one of two replicates had a value and, with this high $C_{t}>40$, was considered negative.

${ }^{f}$ Only one $\mathrm{C}_{\mathrm{t}}$ value of the two was counted for this soil; the other value was $>40$.

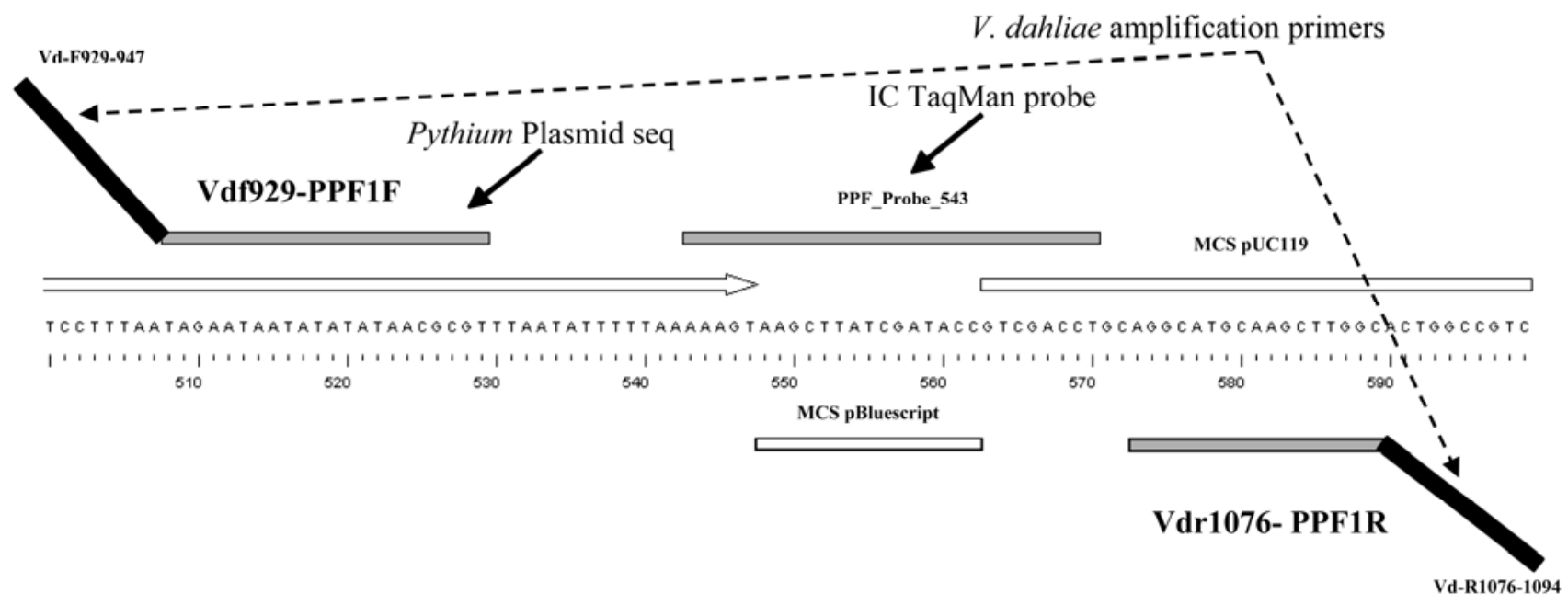

Fig. 1. Diagram of the amplicon used to design the internal control (IC). Primers and probe for the IC assay were based on the clone of mitochondrial Pythium plasmid 96-4 (43). The sequence consisted of a construction of a Pythium plasmid sequence (white arrow) with multiple cloning sites (MCS) of the cloning vectors pBluescript and pUC119. Amplification primers for Verticillium dahliae that were tailed on the end of the plasmid amplification primers are indicated by the black bars. 
To minimize the competition between amplification of the IC and $V$. dahliae target sequences, the following approach for running field soil samples was selected. All samples are first run with the IC at a $10^{-10}$ concentration (amplification product at 0.02 $\mathrm{fg} / \mu \mathrm{l})$. If there was a limited difference in IC amplification compared with the IC control and the $V$. dahliae assay result had a $\mathrm{C}_{\mathrm{t}}>34$, then it was necessary to rerun the assay without the IC added to get an accurate determination of $V$. dahliae. When the $V$. dahliae $\mathrm{C}_{\mathrm{t}}$ is $<29$, the competition with the pathogen template will cause the $\mathrm{C}_{\mathrm{t}}$ of the IC to increase; therefore, the sample should be diluted and rerun to ensure an accurate evaluation of IC amplification and $V$. dahliae quantification.

Consistency of results among DNA extractions. To evaluate the consistency of results among different soil DNA extractions, four soils were extracted five times and the results of the assay for $V$. dahliae compared. Mean $\mathrm{C}_{\mathrm{t}}$ and the level of variation were calculated for all possible combinations of data from a combination of two, three, and four separate extractions (Table 7). The standard deviation in $\mathrm{C}_{\mathrm{t}}$ within each soil replicate was 0.1 to 0.7 , with the lowest values observed for the mean of four replicates. When these data were converted to MS counts, this translated into an $\approx 8 \%$ variation in results when looking at the means of all combinations of four DNA extractions. The means of three replicates gave nearly identical MS counts but with an increase in variation to $\approx 11 \%$. There was one replicate for soil 20 that had a much lower $\mathrm{C}_{\mathrm{t}}$ than the rest of the replicates and was not included in the analysis. In view of this, it was concluded that four DNA extractions should be done for each soil sample because this provides a balance between accuracy of results and soil processing as well as providing a buffer in the event that one DNA extraction gives results far different from the other replicates.
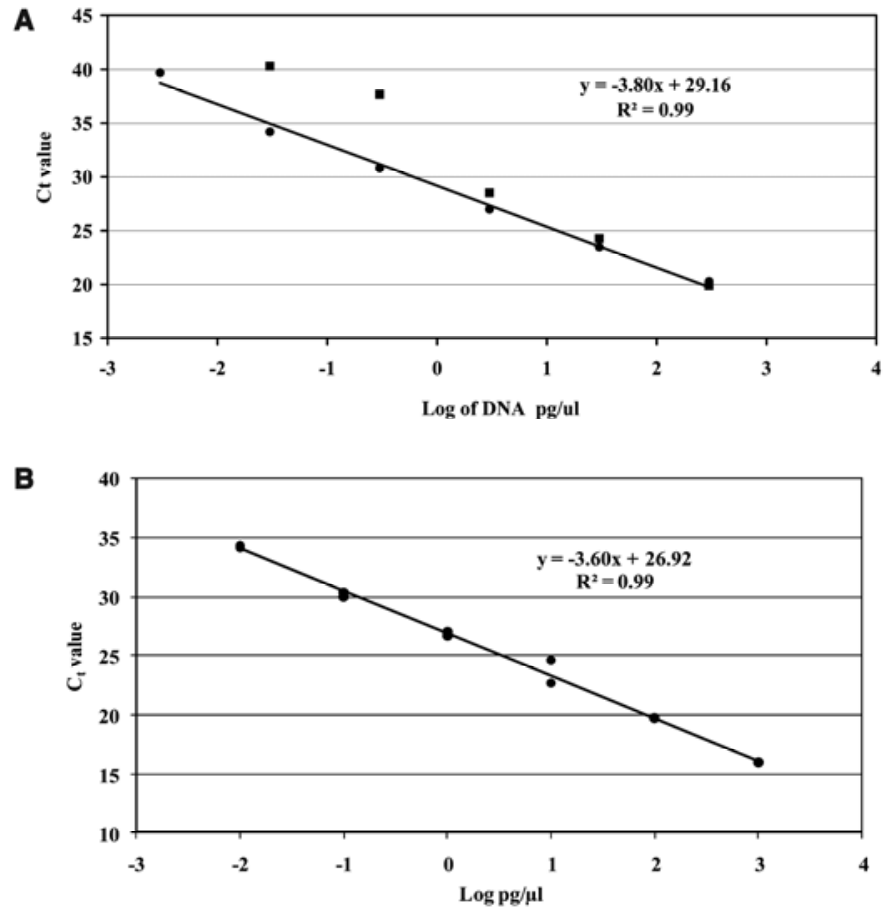

Fig. 2. A, Standard curve of Verticillium dahliae DNA dilution series with cycle threshold $\left(\mathrm{C}_{\mathrm{t}}\right)$ value plotted against the $\log$ of the DNA concentration. Circles and regression analysis represent amplification without the internal control (IC) added. Squares represent the data for amplification with the IC; regression analysis for this data was not done because of polymerase chain reaction competition between the IC and $V$. dahliae target sequences when the pathogen DNA concentration is low, causing the data to be nonlinear above a $\mathrm{C}_{\mathrm{t}}$ of 29. B, Standard curve of V. tricorpus DNA dilution series with $\mathrm{C}_{\mathrm{t}}$ value for the V. tricorpus-specific TaqMan assay plotted against the log of the DNA concentration.
Evaluation of soil DNA extraction procedure using different soil types. When the DNA extraction procedure was tested with a range of soil types encountered in California strawberry production, there was no effect on the amplification of the IC; the $C_{t}$ was the same as was observed in the water control (Table 8). Soil texture types included the following: sand, sandy loam, loam, clay loam, and silty clay loam.

\section{DISCUSSION}

The described TaqMan molecular assay for $V$. dahliae provided an accurate means for quantification of the pathogen in the soil. It was species specific when tested against a range of other Verticillium spp. as well as other common soil fungi and detected all 40 isolates of $V$. dahliae that were collected from a range of hosts and geographic areas and represented different vegetative compatibility groups. The results from this molecular assay had an excellent correlation $\left(R^{2}=0.96\right)$, with pathogen inoculum density ranging from 1 to 2 up to $622 \mathrm{MS} / \mathrm{g}$ of soil in 25 naturally infested field soils, as determined by a standard soil plate assay. Of particular interest for the California strawberry industry is the ability to accurately quantify the lower inoculum densities of the pathogen, with 1 to $4 \mathrm{MS} / \mathrm{g}$ of soil being detected with a $\mathrm{C}_{\mathrm{t}}$ of 34 to 36 , which is in the linear range of the standard curve regression analysis of DNA concentration and $\mathrm{C}_{\mathrm{t}}$. Using a procedure for DNA extraction from the soil that removed many of the PCR inhibitors that could reduce amplification efficiency and targeting the multiple-copy IGS region of the rDNA contributed to this level of sensitivity. Although the three isolates of $V$. longisporum that were tested did not amplify, in view of the recent work by Inderbitzin et al. (28) identifying three lineages of this species that share sequence homology with $V$. dahliae (representatives of lineage A1/D1 and A1/D2 were included in the evaluation), it would be prudent to conduct additional evaluations with lineage A1/D3 of V. longisporum to confirm species specificity of the $V$. dahliae diagnostic markers.

It has been reported that variation in the rDNA IGS sequences is present among Verticillium spp. $(54,58,59)$ and even among different isolates of $V$. dahliae (54); however, based on sequence alignments and the fact that multiple isolates from different hosts and geographic regions were detected, the primer and probe annealing sites used in this assay appear to be highly conserved in $V$. dahliae. In addition to having sequence differences that can be

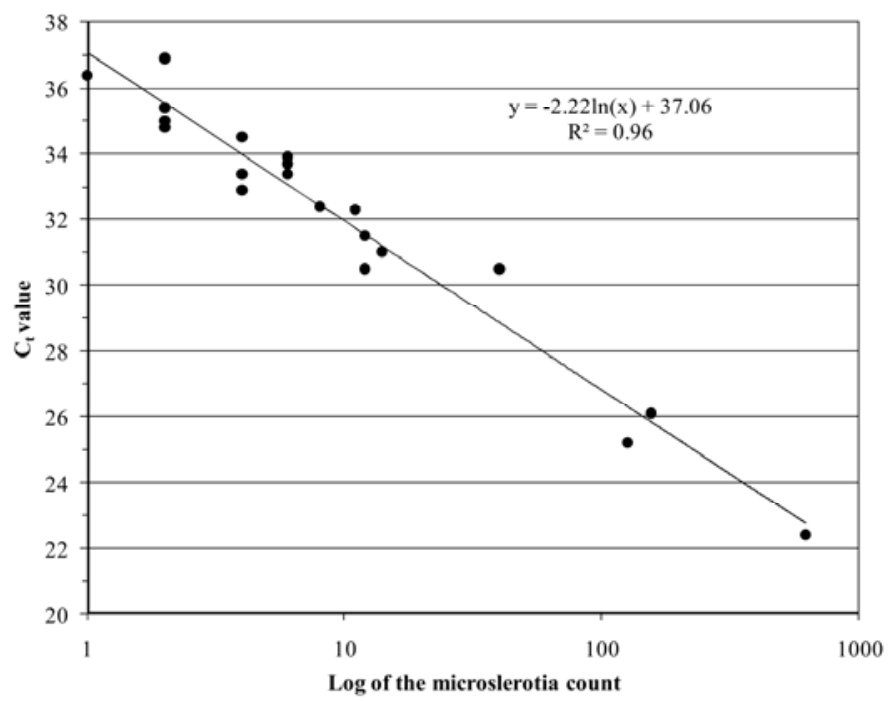

Fig. 3. Linear regression of mean cycle threshold $\left(C_{t}\right)$ value from TaqMan real-time polymerase chain reaction quantitative assay for Verticillium dahliae versus $\log$ of microsclerotia of $V$. dahliae per gram of soil from soil plating of the same soil samples. 
used to design a species-specific TaqMan assay, the IGS region is also present in multiple copies, which increases the sensitivity of the assay compared with single-copy target sequences. Standard curves using DNA isolated from pure cultures indicated that as little as $3 \mathrm{fg}$ of pathogen DNA could be accurately quantified using the assay, and analysis of field soils indicates a lower limit of detection of $1 \mathrm{MS} / \mathrm{g}$ of soil. The copy number of the rDNA in $V$. dahliae is not known; however, using real-time PCR amplification of single-copy genes compared with amplification of the diagnostic amplicon from the IGS region, it was estimated to be $\approx 24$ to 73 copies per haploid genome (average of $\approx 46$ ) depending on the isolate. A similar approach was used for determination of gene copy number variation in Rhesus macaques (13). Given that the amplification efficiency for each of the single-copy genes and the IGS region were different, these values should be considered an estimate only but useful for relative comparison of copy number among isolates. This difference in copy number among isolates could contribute to variability in quantification assays if they were present in the same field; however, based on the raw data obtained during the course of this experimentation, this

TABLE 6. Evaluation of the influence of Verticillium dahliae inoculum density in different field soils and internal control (IC) dilution on the results of the TaqMan real-time polymerase chain reaction (PCR) molecular assay for quantification of $V$. dahliae

\begin{tabular}{|c|c|c|c|c|c|c|}
\hline \multirow[b]{3}{*}{ Soil sample isolates ${ }^{\mathrm{a}}$} & \multicolumn{5}{|c|}{$\mathrm{C}_{\mathrm{t}}$ mean per IC concentration used ${ }^{\mathrm{b}}$} & \multirow[b]{3}{*}{ V. dahliae $(\mathrm{MS} / \mathrm{g})^{\mathrm{c}}$} \\
\hline & \multicolumn{3}{|c|}{ V. dahliae amplification } & \multicolumn{2}{|c|}{ IC amplification } & \\
\hline & No IC & IC $10^{-10}$ & IC $10^{-9}$ & IC $10^{-10}$ & IC $10^{-9}$ & \\
\hline Soil 02 & 32.9 & 33.9 & 34.7 & 35.7 & 31.3 & 6 \\
\hline Soil 06 & 35.6 & 36.9 & 37.3 & 36.3 & 31.2 & 2 \\
\hline Soil 11 & 35.0 & 41.2 & 40.2 & 34.8 & 30.9 & 2 \\
\hline Soil 24 & 25.9 & 26.1 & 26.6 & N/A & 33.2 & 156 \\
\hline Soil 28 & 24.5 & 25.2 & 25.0 & N/A & 35.9 & 126 \\
\hline Soil 29 & 31.4 & 31.5 & 31.4 & 44.6 & 31.2 & 12 \\
\hline Soil 30 & 32.1 & 32.9 & 31.8 & 42.4 & 30.8 & 4 \\
\hline Soil 31 & N/A & N/A & N/A & 34.4 & 30.9 & 0 \\
\hline $\mathrm{H}_{2} \mathrm{O}$ & N/A & N/A & N/A & 34.2 & 30.8 & $\ldots$ \\
\hline
\end{tabular}

a All soil DNA were purified with paramagnetic particles and undiluted.

${ }^{b}$ Mean cycle thresholds $\left(\mathrm{C}_{\mathrm{t}} \mathrm{s}\right)$ are based on two PCR replicates. N/A = no amplification.

c Plate count, microsclerotia per gram of soil.

TABLE 7. Evaluation of the variation in TaqMan real-time polymerase chain reaction results for Verticillium dahliae quantification in soil when replicated DNA extractions are compared ${ }^{\mathrm{a}}$

\begin{tabular}{|c|c|c|c|c|c|c|c|c|c|c|}
\hline \multirow[b]{2}{*}{ Soil } & \multicolumn{4}{|c|}{$\mathrm{C}_{\mathrm{t}}$ value, mean of } & \multirow[b]{2}{*}{$\mathrm{CV}(\%)^{\mathrm{b}}$} & \multicolumn{4}{|c|}{ Calculated microsclerotial counts, mean of ${ }^{c}$} & \multirow[b]{2}{*}{$\mathrm{CV}(\%)^{\mathrm{b}}$} \\
\hline & Two replicates & Three replicates & Four replicates & All replicates & & Two replicates & Three replicates & Four replicates & All replicates & \\
\hline $\mathrm{A}$ & $31.8(0.3)$ & $31.8(0.2)$ & $31.8(0.1)$ & $31.8(0.6)$ & 1.9 & $11.1(1.7)$ & $11.4(0.9)$ & $11.1(0.8)$ & $11.1(3.0)$ & 27 \\
\hline $\mathrm{C}$ & $31.6(0.5)$ & $31.6(0.3)$ & $31.6(0.2)$ & & 2.2 & $12.4(2.2)$ & 12.6 & $12.4(0.9)$ & & 24 \\
\hline $\mathrm{D}$ & $30.8(0.4)$ & $30.8(0.2)$ & $30.8(0.2)$ & $30.8(0.6)$ & 1.9 & $17.8(3.0)$ & $17.9(1.9)$ & $17.8(1.3)$ & $17.8(5.2)$ & 29 \\
\hline
\end{tabular}

a Numbers in parentheses indicate standard deviation between the means obtained for each combination; ... indicates only four replicates used for this soil; one replicate had an inconsistent reading with a cycle threshold $\left(\mathrm{C}_{\mathrm{t}}\right)$ of 28 that was not included in the analysis.

${ }^{\mathrm{b}}$ Coefficient of variation.

${ }^{\mathrm{c}}$ Calculation equation: $y=-2.224 \ln (x)+37.063, R^{2}=0.9565$.

TABLE 8. Evaluation of the DNA extraction procedure on the ability to obtain DNA from different soil types collected from commercial strawberry production fields in California that can be amplified in the Verticillium dahliae TaqMan real-time polymerase chain reaction diagnostic assay

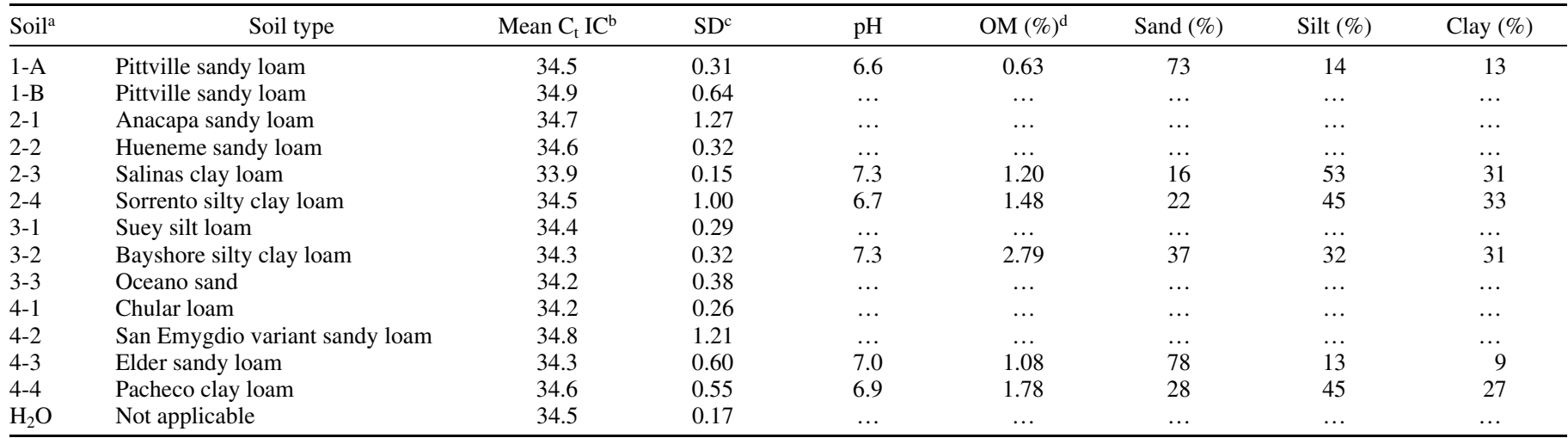

${ }^{a}$ Soil numbers indicate soil used from 1, strawberry transplant region, nursery, Fall River Valley; 2-1, Ventura County strawberry fields; 3, Santa Maria strawberry fields; and 4, Salinas, Watsonville strawberry fields.

${ }^{\mathrm{b}}$ Internal control (IC) concentration used $10^{-10}$ dilution.

${ }^{c}$ Standard deviation between the different cycle thresholds $\left(\mathrm{C}_{\mathrm{t}} \mathrm{s}\right)$ used for the mean $\mathrm{C}_{\mathrm{t}}$ based on three replicates.

d Organic matter. 
should account for a difference in the final $\mathrm{C}_{\mathrm{t}}$ of $\approx 1.8$. With the high correlation $\left(R^{2}=0.96\right)$ observed for comparison between the molecular quantification and microsclerotial plate counts for the field soils collected from a range of locations in California, it does not appear that this possibility of copy number variation among isolates appreciably affected the accuracy of our results. Variation in rDNA copy number has been reported in a number of eumycotan fungal genera $(5,41,48,55,57)$.

The sensitivity of this assay allowed accurate detection of 1 to $2 \mathrm{MS} / \mathrm{g}$ and $3 \mathrm{fg}$ of pure $V$. dahliae DNA, which is a lower level relative to other assays for this pathogen. With conventional competitive PCR, Mahuku and Platt (40) had a maximum sensitivity of $5 \mathrm{MS} / \mathrm{g}$ of soil. Using the single-copy gene $\beta$-tubulin for detection of $V$. dahliae in potato, Atallah et al. (2) reported a limit of detection of $148 \mathrm{fg}$ of pathogen DNA. Likewise, using an ITS target sequence and SYBR Green real-time PCR, Lievens et al. (38) reported a detection limit of 8 to $13 \mathrm{MS}$ and purified pathogen DNA at $1 \mathrm{pg} / \mu \mathrm{l}$. Compared with these techniques, the addition of a TaqMan probe in the assay reported herein could potentially improve the specificity of detection by adding an additional annealing site in order to get a positive amplification.

The IC was an important part of this $V$. dahliae assay because it provided a means to evaluate the presence of PCR inhibitors in the sample. This not only prevented false negative results (if only the pathogen probe was present there would be no way to determine whether the lack of amplification was due to the absence of the pathogen or the inability of amplification to take place due to PCR inhibitors) but also allowed for normalization of results when inhibitors were present in low amounts, which led to more accurate quantification of the pathogen. The cloned mitochondrial plasmid of $P$. aphanidermatum was chosen as a template for the IC because of its limited distribution in Pythium spp. (42) making it uncommon in the soil. The uniqueness of the IC was further enhanced by targeting a combination of sequences from the mitochondrial plasmid and multiple cloning sites of the plasmid cloning vectors for the TaqMan probe (Fig. 1). Designing the IC so that it used the same amplification primers as $V$. dahliae target sequences further simplified running the assay. Depending on the concentration of the IC added to the master mix and the inoculum density of $V$. dahliae that was present in the soil, some competition in the amplification of the IC or pathogen target was observed. However, the impact of this competition on the accuracy of the results could be moderated by rerunning the assays without adding the IC (if the $\mathrm{C}_{\mathrm{t}}>34$ ) or by diluting the soil DNA extract $\left(C_{t}<29\right)$.

An IC also has been used in real-time PCR quantification assays of other microorganisms. Plant sequences were targeted as an IC for assays designed to determine the amount of the pathogen in potato tissue by using a ratio of the amplification results of plant and pathogen to quantify colonization levels $(2,3,10)$. Although this approach may be useful for quantification in plant tissue, other target sequences are needed for assays focusing on the soil, and the IC template should be added to the master mix to ensure that an equal amount is present for each amplification. For quantification of a bacterial biocontrol agent (67) and Ralstonia solanacearum (27), an exogenous plasmid and commercially available IC template, respectively, was added to the master mix. Exogenous plasmids were also used as an IC for assays quantifying pathogens responsible for Fusarium crown rot (25) and Synchytrium endobioticum (66), while purified DNA from another fungal species was added as the IC template for quantification of soilborne fungal potato pathogens (4). In these examples, the amplification primers for the IC were different from the target organism; however, designing an IC that uses the same amplification primers as the target pathogen will simplify setting up the amplification reactions. This was the approach used for the assay for $V$. dahliae described herein and was patterned after the techniques used for quantification of Enterovirus spp. (19) from water samples and hepatitis B virus (39). Recently, Haudenshield et al. (21) described a similar approach with several ICs for quantification of Phakopsora pachyrhizi.

Before a molecular assay can be used to quantify the amount of a pathogen in the soil, basic information on the consistency of results observed between replicate samples is needed so that a sampling strategy can be devised that will provide accurate results without unnecessary sample processing. In an effort to assess this for the $V$. dahliae assay, five replicate samples of several soils were processed and the means calculated for all possible combinations of three and four replicate samples (Table 7). It was concluded that running four replicate samples was advisable when processing field samples because this would provide some buffering to account for "outliers" that should be discarded. This higher level of variation in the result that was observed for one replicate of soil 20 could be due to nonuniform distribution of inoculum in the soil or, perhaps, be caused by organic matter containing a cluster of MS that was not completely disrupted during grinding of the dry soil prior to DNA extraction.

One approach that could improve the sensitivity and accuracy of this assay when low inoculum densities are present is to increase the amount of soil that is used for DNA extraction. Due to the size of the tubes currently used for DNA extraction and the volume of extraction buffer they can hold, the current upper limit is $0.5 \mathrm{~g}$ of soil per extraction; increasing the amount of soil will result in a lower yield of DNA, with more PCR inhibitors persisting through the extraction procedure. With this small amount of soil, more variation in the results of the real-time assay may be encountered for low inoculum density soils $(<4 \mathrm{MS} / \mathrm{g})$ due strictly to the likelihood that pathogen inoculum distribution is not completely uniform. Although extraction tubes capable of holding a total of $15 \mathrm{ml}$ are available for the FastPrep instrument and would allow greater amounts of soil to be processed, this would also significantly increase the cost of running the assay due to the need for much larger volumes of extraction buffer. Running three to four replicate DNA extractions with sample tubes capable of holding $2 \mathrm{ml}$ of total volume $(0.5 \mathrm{~g}$ of soil each) gives adequate consistency in results with minimal increase in processing cost. Another approach described by Debode et al. (12) used sucrose flotation of soil suspensions for concentrating MS from soil. This procedure could significantly increase the accuracy of quantification of soils with a low inoculum density by allowing much larger amounts of soil to be processed in each DNA extraction.

One advantage of using a molecular approach for quantification of $V$. dahliae in the soil is that the specificity of the assay eliminates possible interference from other Verticillium spp. The recent report by Inderbitzin et al. (28) confirms that $V$. longisporum is a hybrid species with $V$. dahliae as one parent; however, the colony morphology of this hybrid species on NP-10 medium used for soil plating assays cannot be differentiated from V. dahliae (morphological differentiation of these species is based on more elongated conidia for V. longisporum) (34). This could lead to incorrect soil inoculum density estimates of $V$. dahliae using soil plating when $V$. longisporum is present. Likewise, it can sometimes be difficult to differentiate colonies of $V$. dahliae from $V$. tricorpus. As noted by Good et al. (17), formation of MS in $V$. dahliae colonies has a more radial pattern, consisting of profuse numbers of MS with larger globose to irregular-shaped MS, compared with a scattered MS pattern for $V$. tricorpus, with fewer MS produced having more of an oval to blocky shape. The colonies of $V$. tricorpus have been reported to produce a yellow pigment as well but, in our experience, this is not always the case. Having an accurate molecular assay to confirm the identity of ambiguous colonies improved the accuracy of our $V$. dahliae plate counts.

The assay developed for $V$. tricorpus was also specific for this species and was a useful tool to confirm the identity of Verticillium spp. on NP-10 soil assay plates. Studies are currently in 
progress evaluating the use of this marker for quantification of $V$. tricorpus in soil samples using the same approach as described for $V$. dahliae; however, evaluation of additional isolates of $V$. tricorpus is needed to confirm marker specificity. Preliminary analysis of one isolate from tomato in the United Kingdom (MUCL9792) that was provided as V. tricorpus was not detected by this marker; sequence analysis of the IGS region for this isolate revealed polymorphisms in primer and probe annealing sites, and the sequence was different from all other Verticillium spp. in GenBank (G. Bilodeau and F. Martin, unpublished). It was recently reported that $V$. tricorpus causing lettuce wilt in Japan was genetically distinct from California lettuce isolates of this species (64), indicating that additional taxonomic work is needed to clarify species boundaries and the correct classification of these isolates.

One possible shortcoming when using molecular techniques for quantifying a soilborne pathogen that may influence the accuracy of results is that nonviable propagules have the potential to contribute DNA to the assay, thereby causing incorrect quantification. The length of time DNA may remain intact in nonviable propagules of $V$. dahliae in the soil is unknown and may be influenced by a range of factors such as soil moisture or the degree to which MS resist decay. Some insight into this for $V$. dahliae may be gleaned from observations for field soil 26 , which had an inoculum density of $622 \mathrm{MS} / \mathrm{g}$ of soil in plate counts when initially sampled but, when resampled 5 months after the field was commercially fumigated with methyl bromide + chloropicrin, the plate counts and results of the molecular assay indicated negligible levels of $V$. dahliae (data not shown). The excellent correlation between molecular results and plate counts of viable MS $\left(R^{2}=0.96\right)$ (Fig. 3) obtained for a range of soils in this experimentation suggests that nonviable propagules have not compromised the final results.

The described TaqMan soil assay should provide an accurate and rapid means for quantification of $V$. dahliae over a wide range of inoculum densities in agricultural soils. The ability to use commercial DNA extraction kits without the use of organic solvents, the potential for using robotic techniques for DNA extraction, and a 96-well format for processing samples will facilitate high-throughput analysis. The ability to accurately quantify low inoculum levels will be particularly useful for the California strawberry industry because this host is highly susceptible to $V$. dahliae. Although this technique was effective for quantification of $V$. dahliae in the soil samples we processed, before it is implemented on a larger scale in regions with different soils a full validation comparing the results with plate counts should be completed to ensure the accuracy of results. Whereas the soil DNA extraction procedure used for purifying template DNA was found to be effective on a range of soil types from California strawberry fields, there is no guarantee that it will be as effective in providing clean template DNA from all soil types. This can have an influence not only on the accuracy of the assay but also on the relationship between $\mathrm{C}_{t}$ and microsclerotial counts. It should be noted that the brand of the real-time PCR master mix can have an influence on the sensitivity of this assay. Initial validation trials of the $V$. dahliae diagnostic assay were run with TaqMan Universal Master Mix (Applied Biosystems); however, switching to the Real Master Mix without Rox (5 Prime) increased the sensitivity of the assay by reducing the $C_{t}$ values by 4 to 6 depending on the concentration of the target sequences. The species-specific marker for $V$. dahliae described herein should also be useful for pathogen identification and quantification in plant tissue although, for the latter purpose, another IC that will allow comparison of the quantity of pathogen relative to the plant DNA will need to be used. Likewise, due to the unique sequence of the IC and the ease with which it can be modified to be amplified with other primers, the IC from the $V$. dahliae assay could also be used in other molecular quantification assays.

\section{NOTE ADDED IN PROOF}

Debode et al. recently published their work using sucrose flotation to recover microsclerotia as part of their molecular soil quantification assay in addition to a new SYBR green detection assay for $V$. dahliae, V. longisporum, and V. tricorpus (Plant Dis. 95:1571-1580). Inderbitzin et al. recently reported a multilocus phylogenetic analysis of the genus Verticillium and V. tricorpus isolates Ls442 and Ls443 used in this study have been reclassified as $V$. isaacii and the V. albo-atrum isolate Ms102 has been reclassified as $V$. alfalfae (PLos ONE 6:e28341).

\section{ACKNOWLEDGMENTS}

We thank the California Strawberry Commission for providing funding to support this research; K. Kammeijer and L. Murphy (University of California Cooperative Extension Monterey County, Salinas) for conducting the soil plating; Driscolls Strawberry, O. Daugovish, D. Maloney, D. Marcum, and G. Omori for providing field soils for validation; L. Myer for her work on isolating and identifying soil fungi; R. M. Jiménez-Díaz (Universidad de Córdoba, Spain), K. Dobinson (Agriculture and Agrifood Canada [AAC], London, Ontario, Canada), H. (Bud) Platt (AAC, Charlottetown. P.E.I, Canada), and B. Lievens (Scientia Terrae Research Institute, Sint-Katelijne-Waver, Belgium) for providing DNA from Verticillium spp.; and K. Subbarao (University of California, Davis) and L. du Toit (Washington State University) for providing cultures.

\section{LITERATURE CITED}

1. Altschul, S. F., Madden, T. L., Schäffer, I. A., Zhang, J., Zhang, Z., Miller, W., and Lipman, D. J. 1997. Gapped BLAST and PSI-BLAST: A new generation of protein database search programs. Nucleic Acids Res. 25:3389-3402.

2. Atallah, Z. K., Bae, J., Jansky, S. H., Rouse, D. I., and Stevenson, W. R. 2007. Multiplex real-time quantitative PCR to detect and quantify Verticillium dahliae colonization in potato lines that differ in response to Verticillium wilt. Phytopathology 97:865-872.

3. Atallah, Z. K., and Stevenson, W. R. 2006. A methodology to detect and quantify five pathogens causing potato tuber decay using real-time quantitative polymerase chain reaction. Phytopathology 96:1037-1045.

4. Brierley, J. L., Stewart, J. A., and Lees, A. K. 2009. Quantifying potato pathogen DNA in soil. Appl. Soil Ecol. 41:234-238.

5. Butler, D. K., and Metzenberg, R. L. 1989. Premeiotic change of nucleolous organizer size in Neurospora. Genetics 122:783-791.

6. Butterfield, E. J., and DeVay, J. E. 1977. Reassessment of soil assays for Verticillium dahliae. Phytopathology 67:1073-1078.

7. CDFA. 2011. California Agricultural Resource Directory 2010-2011. CDFA, ed. California Department of Food and Agriculture. Published Online http://www.cdfa.ca.gov/statistics/PDFs/ResourceDirectory_20102011.pdf.

8. Collado-Romero, M., Mercado-Blanco, J., Olivares-García, C., and Jiménez-Díaz, R. M. 2008. Phylogenetic analysis of Verticillium dahliae vegetative compatibility groups. Phytopathology 98:1019-1028.

9. Collado-Romero, M., Mercado-Blanco, J., Olivares-García, C., ValverdeCorredor, A., and Jiménez-Díaz, R. M. 2006. Molecular variability within and among Verticillium dahliae vegetative compatibility groups determined by fluorescent amplified fragment length polymorphism and polymerase chain reaction markers. Phytopathology 96:485-495.

10. Cullen, D. W., Toth, I. K., Boonham, N., Walsh, K., Barker, I., and Lees, A. K. 2007. Development and validation of conventional and quantitative polymerase chain reaction assays for the detection of storage rot potato pathogens, Phytophthora erythroseptica, Pythium ultimum and Phoma foveata. J. Phytopathol. 155:309-315.

11. Dan, H., Ali-Khan, S. T., and Robb, J. 2001. Use of quantitative PCR diagnostics to identify tolerance and resistance to Verticillium dahliae in potato. Plant Dis. 85:700-705.

12. Debode, J., Van Poucke, K., Franca, S. C., Höfte, M., Maes, M., and Heungens, K. 2009. Quantitative detection of multiple Verticillium species in soil using real-time PCR. In: 10th Int. Verticillium Symp. Corfu Island, Greece.

13. Degenhardt, J. D., de Candia, P., Chabot, A., Schwartz, S., Henderson, L., Ling, B., Hunter, M., Jiang, Z., Palermo, R. E., Katze, M., Eichler, E. E., Ventura, M., Rogers, J., Marx, P., Gilad, Y., and Bustamante, C. D. 2009. Copy number variation of $C C L 3$-like genes affects rate of progression to 
simian-AIDS in rhesus macaques (Macaca mulatta). PLoS Genet. 5:e1000346.

14. Dhingra, O. D., and Sinclair, J. B. 1985. Basic Plant Pathology Methods. CRC Press, Boca Raton, FL.

15. Dorak, M. T. 2006. Real-time PCR. In: Bios Advanced Methods Series. Taylor \& Francis, Oxford

16. Garcia-Pedrajas, M. D., Bainbridge, B. W., Heale, J. B., Perez-Artes, E., and Jimenez-Diaz, R. M. 1999. A simple PCR-based method for the detection of the chickpea-wilt pathogen Fusarium oxysporum f. sp. ciceris in artificial and natural soils. Eur. J. Plant Pathol. 105:251-259.

17. Goud, J., Termorshuizen, A., and Gams, W. 2003. Morphology of Verticillium dahliae and V. tricorpus on semi-selective media used for the detection of $V$. dahliae in soil. Mycol. Res. 107:822-830.

18. Goud, J. C., and Termorshuizen, A. J. 2003. Quality of methods to quantify microsclerotia of Verticillium dahliae in soil. Eur. J. Plant Pathol. 109:523-534.

19. Gregory, J. B., Litaker, R. W., and Noble, R. T. 2006. Rapid one-step quantitative reverse transcriptase PCR assay with competitive internal positive control for detection of enteroviruses in environmental samples. Appl. Environ. Microbiol. 72:3960-3967.

20. Harris, D. C., and Yang, J. R. 1996. The relationship between the amount of Verticillium dahliae in soil and the incidence of strawberry wilt as a basis for disease risk prediction. Plant Pathol. 45:106-114.

21. Haudenshield, J. S., and Hartman, G. L. 2011. Exogenous controls increase negative call veracity in multiplexed, quantitative PCR assays for Phakopsora pachyrhizi. Plant Dis. 95:343-352.

22. Haugland, R., Siefring, S., Wymer, L., Brenner, K., and Dufour, A. 2005. Comparison of measurements in freshwater at two recreational beaches by quantitative polymerase chain reaction and membrane filter culture analysis. Water Res. 39:559-568.

23. Heid, C. A., Stevens, J., Livak, K. J., and Williams, P. M. 1996. Real-time quantitative PCR. Genome Res. 6:986-994.

24. Heinz, R. A., and Platt, H. W. B. 2000. Improved DNA extraction method for Verticillium detection and quantification in large-scale studies using PCR-based techniques. Can. J. Plant Pathol. 22:117-121.

25. Hogg, A. C., Johnston, R. H., Johnston, J. A., Klouser, L., Kephart, K. D., and Dyer, A. T. 2010. Monitoring Fusarium crown rot populations in spring wheat residues using quantitative real-time polymerase chain reaction. Phytopathology 100:49-57.

26. Hu, X., Nazar, R. N., and Robb, J. 1993. Quantification of Verticillium biomass in wilt disease development. Physiol. Mol. Plant Pathol. 42:2336.

27. Huang, J., Wu, J., Li, C., Xiao, C., and Wang, G. 2009. Specific and sensitive detection of Ralstonia solanacearum in soil with quantitative, real-time PCR assays. J. Appl. Microbiol. 107:1729-1739.

28. Inderbitzin, P., Davis, R. M., Bostock, R. M., and Subbarao, K. V. 2011. The Ascomycete Verticillium longisporum is a hybrid and a plant pathogen with an expanded host range. Plos One 6:e18260.

29. Kabir, Z., Bhat, R. G., and Subbarao, K. V. 2004. Comparison of media for recovery of Verticillium dahliae from soil. Plant Dis. 88:49-55.

30. Kageyama, K., Komatsu, T., and Suga, H. 2003. Refined PCR protocol for detection of plant pathogens in soil. J. Gen. Plant Pathol. 69:153-160.

31. Kapulnik, E., Quick, J., and DeVay, J. E. 1985. Germination of propagules of Verticillium dahliae in soil treated with methionine and other substances affecting ethylene production. (Abstr.) Phytopathology 75:1348.

32. Karapapa, V. K., Bainbridge, B. W., and Heale, J. B. 1997. Morphological and molecular characterization of Verticillium longisporum comb. nov., pathogenic to oilseed rape. Mycol. Res. 101:1281-1294.

33. Klonsky, K. M., and De Moura, R. L. 2001. Sample costs to produce fresh market strawberries-central coast region-Monterey and Santa Cruz counties. In: UC Davis ag econ study. Univ. Calif. Coop. Ext. Bull. STCC-01.

34. Klosterman, S. J., Atallah, Z. K., Vallad, G. E., and Subbarao, K. V. 2009. Diversity, pathogenicity, and management of Verticillium species. Annu. Rev. Phytopathol. 47:39-62.

35. Koike, S. T., Subbarao, K. V., Davis, R. M., Gordon, T. R., and Hubbard, J. C. 1994. Verticillium wilt of cauliflower in California. Plant Dis. 78:1116-1121.

36. Lees, A. K., Cullen, D. W., Sullivan, L., and Nicolson, M. J. 2002. Development of conventional and quantitative real-time PCR assays for the detection and identification of Rhizoctonia solani AG-3 in potato and soil. Plant Pathol. 51:293-302.

37. Li, K. N., Rouse, D. I., Eyestone, E. J., and German, T. L. 1999. The generation of specific DNA primers using random amplified polymorphic DNA and its application to Verticillium dahliae. Mycol. Res. 103:13611368

38. Lievens, B., Brouwer, M., Vanachter, A. C. R. C., Cammue, B. P. A., and Thomma, B. P. H. J. 2006. Real-time PCR for detection and quantification of fungal and oomycete tomato pathogens in plant and soil samples. Plant
Sci. 171:155-165.

39. Lole, K. S., and Arankalle, V. A. 2006. Quantitation of hepatitis B virus DNA by real-time PCR using internal amplification control and dual TaqMan MGB probes. J. Virol. Methods 135:83-90.

40. Mahuku, G. S., and Platt, H. W. 2002. Quantifying Verticillium dahliae in soils collected from potato fields using a competitive PCR assay. Am. J. Potato Res. 79:107-117.

41. Maleszka, R., and Clark-Walker, G. D. 1993. Yeasts have a four-fold variation in ribosomal DNA copy number. Yeast 9:53-58.

42. Martin, F. N. 1991. Characterization of circular mitochondrial plasmids in three Pythium species. Curr. Genet. 20:91-97.

43. Martin, F. N. 2003. Development of alternative strategies for management of soilborne pathogens currently controlled with methyl bromide. Annu. Rev. Phytopathol. 41:325-350.

44. Martin, F. N., and Bull, C. T. 2002. Biological approaches for control of root pathogens of strawberry. Phytopathology 92:1356-1362.

45. Nazar, R. N., Hu, X., Schmidt, J., Culham, D., and Robb, J. 1991. Potential used of PCR-amplified ribosomal intergenic sequences in the detection and differentiation of Verticillium wilt pathogens. Physiol. Mol. Plant Pathol. 39:1-11.

46. Okubara, P. A., Li, C. Q., Schroeder, K. L., Schumacher, R. T., and Lawrence, N. P. 2007. Improved extraction of Rhizoctonia and Pythium DNA from wheat roots and soil samples using pressure cycling technology. Can. J. Plant Pathol. 29:304-310.

47. Okubara, P. A., Schroeder, K. L., and Patilitz, T. C. 2008. Identification and quantification of Rhizoctonia solani and $R$. oryzae using real-time polymerase chain reaction. Phytopathology 98:837-847.

48. Pasero, P., and Marilly, M. 1993. Size variation rDNA clusters in the yeasts Saccharomyces cerevisiae and Saccharomyces pombe. Mol. Gen. Genet. 236:448-452

49. Pegg, G. F., and Brady, B. L. 2002. Verticillium Wilts. CABI Publishing, New York.

50. Pérez-Artés, E., Mercado-Blanco, J., Ruz-Carrillo, A. R., RodríguezJurado, D., and Jiménez-Díaz, R. M. 2005. Detection of the defoliating and nondefoliating pathotypes of Verticillium dahliae in artificial and natural soils by nested PCR. Plant Soil 268:349-356.

51. Peters, J., O’Neill, T., Green, K., Woodhall, J., Barnes, A., and Lane, C. 2009. Using real-time PCR to determine risk of strawberry wilt from infested soil. In: 10th Int. Verticillium Symp. Corfu Island, Greece.

52. Pfaffl, M. W. 2001. A new mathematical model for relative quantification in real-time RT-PCR. Nucleic Acids Res. 29:E45.

53. Platt, H. W., and Mahuku, G. 2000. Detection methods for Verticillium species in naturally infested and inoculated soils. Am. J. Potato Res. 77:271-274.

54. Pramateftaki, P. V., Antoniou, P. P., and Typas, M. A. 2000. The complete DNA sequence of the nuclear ribosomal RNA gene complex of Verticillium dahliae: Intraspecific heterogeneity within the intergenic spacer region. Fungal Genet. Biol. 29:19-27.

55. Pukkila, P. J., and Skrzynia, C. 1993. Frequent changes in the number of reiterated ribosomal RNA genes throughout the lifecycle of the basidiomycete Coprinus cinereus. Genetics 133:203-211.

56. Qin, Q.-M., Vallad, G. E., Wu, B. M., and Subbarao, K. V. 2006. Phylogenetic analyses of phytopathogenic isolates of Verticillium spp. Phytopathology 96:582-592.

57. Rustchenko-Bulgac, E. P., Curran, T., and Sherman, F. 1993. Variation in the number of ribosomal DNA subunits in morphological mutants and normal strains of Candida albicans and in normal strains of Saccharomyces cerevisiae. J. Bacteriol. 175:7189-7199.

58. Schena, L., Nigro, F., and Ippolito, A. 2004. Real-time detection and quantification of soilborne fungal pathogens: The case of Rosellinia necatrix, Phytophthora nicotianae, P. citrophthora and Verticillium dahliae. Phytopathol. Mediterr. 43:273-280.

59. Schena, L., Nigro, F., Ippolito, A., and Gallitelli, D. 2004. Real-time quantitative PCR: A new technology to detect and study phytopathogenic and antagonistic fungi. Eur. J. Plant Pathol. 110:893-908.

60. Sorensen, L. H., Schneider, A. T., and Davis, J. R. 1991. Influence of sodium polygalacturonate sources and improved recovery of Verticillium species from soil. (Abstr.) Phytopathology 81:1347.

61. Stark, J. C. 1961. Das aufreten der Verticillium: Tracheomykosen in Hamburger Gartenbaukulturen. Gartenbauwissenschaft 26:493-528.

62. Stelzl, E., Muller, Z., Marth, E., and Kessler, H. H. 2004. Rapid quantification of hepatitis B virus DNA by automated sample preparation and real-time PCR. J. Clin. Microbiol. 42:2445-2449.

63. Termorshuizen, A. J., Davis, J. R., Gort, G., Harris, D. C., Huisman, O. C., Lazarovits, G., Locke, T., Vara, J. M. M., Mol, L., Paplomatas, E. J., Platt, H. W., Powelson, M., Rouse, D. I., Rowe, R. C., and Tsror, L. 1998. Interlaboratory comparison of methods to quantify microsclerotia of Verticillium dahliae in soil. Appl. Environ. Microbiol. 64:3846-3853.

64. Usami, T., Takeshi, K., Inderbitzin, P., Itoh, M., Kisaki, G., Ebihara, Y., Suda, W., Amemiya, Y., and Subbarao, K. V. 2011. Verticillium tricorpus 
causing lettuce wilt in Japan differs genetically from California lettuce isolates. J. Gen. Plant Pathol. 77:17-23.

65. van Doorn, J., Khanh, K. T. K., and Hiemstra, J. A. 2009. Molecular detection of Verticillium dahliae in soil. In: 10th Int. Verticillium Symp. Corfu Island, Greece.

66. van Gent-Pelzer, M. P. E., Krijger, M., and Bonants, P. J. M. 2010. Improved real-time PCR assay for detection of the quarantine potato pathogen, Synchytrium endobioticum, in zonal centrifuge extracts from soil and in plants. Eur. J. Plant Pathol. 126:129-133.
67. Von Felten, A., Defago, G., and Maurhofer, M. 2010. Quantification of Pseudomonas fluorescens strains F113, CHA0 and Pf153 in the rhizosphere of maize by strain-specific real-time PCR unaffected by the variability of DNA extraction efficiency. J. Microbiol. Methods 81:108-115.

68. White, T. J., Bruns, T., Lee, S., and Taylor, J. 1990. Amplification and direct sequencing of fungal ribosomal RNA genes for phylogenetics. Pages 315-322 in: PCR Protocols. A Guide to Methods and Applications. D. H. G. M. A. Innis, J. J. Sninsky, and T. J. White, eds. Academic Press, Inc., San Diego, CA. 